\title{
MINISTRO CARLOS THOMPSON FLORES (Centenário do seu nascimento)
}

\author{
Carlos Eduardo Thompson Flores Lenz \\ Desembargador Federal do TRF $/ 4^{a}$ Região
}

"Justiça que brote de Juízes independentes, sem falsos ou mal compreendidos exageros. Justiça austera, impoluta, incorruptível, como se faz mister que o seja, e para cujos imperativos prosseguiremos indormidos e intransigentes. Justiça humana, como merece distribuída às criaturas, feita à imagem de Deus. Justiça que jamais se aparte dos fins sociais e das exigências do bem comum, sem cujo conteúdo não teria nenhum sentido. Justiça que se aproxime, sem excessos ou enganosas formas, do próprio Povo, para o qual é ditada e do qual deve estar sempre ao alcance: simples, real, despida de tudo que a possa tornar dificultosa, a fim de que a compreenda melhor, sinta-a com mais fervor, e possa, assim, nela crer, para amá-la, prestigiá-la e defendê-la, se preciso for, convencido de que ela é o seu baluarte democrático e a sua mais sólida garantia. E, sobretudo, Justiça pontual, como a queria Rui, porque tarda não mereceria o nobre título. E como dizia, reclamando,
"Para que paire mais alto que a coroa dos reis e seja tão pura como a coroa dos santos".

Só assim nos tornaremos dignos do respeito e da confiança da Nação, ao lado dos demais Poderes da República"

Ministro Carlos Thompson Flores

Ao discursar na homenagem a Carlos Thompson Flores, em 14 de fevereiro de 1977, que então se empossava na Presidência do Supremo Tribunal Federal, o Ministro Moreira Alves teve a oportunidade de dizer, em análise percuciente, a propósito de sua personalidade como magistrado nestas palavras consagradoras, verbis:

"Neste ano e meio em que tenho a honra de integrar esta Casa, servindo na Turma a que até agora Vossa Excelência presidia, pude sentir de perto, em convivência quase diária, a 
justiça que se lhe tem feito ao longo de sua vida de magistrado. Tenho-o, Sr. Min. THOMPSON FLORES, por modelo de juiz. Vossa Excelência, no exercício da judicatura, revela não limitar-se a possuir aquelas qualidades que MURATORI, apoiado nas santas escrituras e veemente na crítica aos juristas, exigia dos juízes: o saber, para bem aplicar as leis; o amar a verdade, para poder distinguila do erro; o temor a Deus, para não deixar-se levar pelo ódio, medo, cupidez ou qualquer outra inclinação; o desprezar as posições e regalias, para ser imparcial. A esses atributos, acrescenta-se, em Vossa Excelência, um outro: o exercer a magistratura como sacerdócio, com o amor de quem nela, e só por ela, realiza o ideal de suas aspirações."1

Logo em seguida, o ProcuradorGeral da República, o Professor Henrique Fonseca de Araújo, em nome do Ministério Público Federal, traduziu, com estas belas e significativas orações, os mesmos sentimentos, verbis:

"Tanto impressionou-me o espírito de justiça de que impregnava seus pronunciamentos, que disse certa vez a Sua Excelência, que, se porventura, um dia fosse eu réu em um processo, o escolheria para juiz, renunciando previamente a qualquer recurso. Não tive motivos, continuando a acompanhar-lhe a judicatura, muito especialmente neste colendo Tribunal, para alterar, antes para confirmar esse juízo que, de resto é o de todos que o têm visto atuar como magistrado.

Em Sua Excelência, nos seus julgamentos, tenho encontrado a confirmação do que ensina RECASENS SICHES, de que a lógica jurídica não é igual ao tipo de lógica matemática, porque é a lógica do razoável. A sentença, na sua elaboração, não obedece necessariamente ao clássico silogismo. Porque, "sentença", já na sua etimologia latina, vem do verbo "sentice", o que equivale a dizer, experimentar uma espécie de emoção, dir-se-ia, uma espécie de intuição emocional. Juiz, ao conhecer dos fatos, forma, antes de mais nada, sua conclusão, pelo seu inato espírito de justiça, numa demonstração de que o "decisum", em regra, se estabelece no espírito do juiz, antes dos "consideranda". Essa, também, a opinião de CALAMANDREI.

$O$ eminente Min. THOMPSON FLORES sente, intuitivamente, onde está a Justiça. Se algo caracteriza sua personalidade de magistrado é esse inato espírito de justiça, servido por um caráter incorruptível e inamoldável, onde a bravura e o destemor não chegam a ressaltar por sua naturalidade.

Contra os poderosos do dia, presidiu, certa feita, como Juiz, júri de imprensa. E contra tudo e contra todos, levou o Tribunal à unânime

1 In: Revista Forense, v. 257, p. 418. 
decisão condenatória, que lhe valeu ameaças e insultos, que em nada alteraram sua conduta.

Por suas qualidades é que, sem bairrismo, nós, rio-grandenses do Sul, nos orgulhamos do Min. THOMPSON FLORES.”2

Com efeito, após 44 anos dedicados exclusivamente à magistratura, atingira o cume de sua vitoriosa carreira, repetindo, no plano nacional, a consagração que obtivera em seu estado natal, o Rio Grande do Sul.

Quanto mais se examina a vida de Carlos Thompson Flores, mais se revela a sua vocação para a função de juiz.

Por certo, herdou-a de seu avô, o também Desembargador Carlos Thompson Flores, fundador e primeiro Diretor da Faculdade de Direito de Porto Alegre, Presidente da Província no Império, parlamentar, constituinte em 1891 e membro do Tribunal de Justiça tão logo proclamada a República.

Aos 26 de janeiro de 1911, há cem anos, nasceu Carlos Thompson Flores na cidade de Montenegro, no Estado do Rio Grande do Sul.

Filho do político e advogado Luiz Carlos Reis Flores e de Dona Francisca Abbott Borges Fortes Flores, foram os seus avôs paternos o Desembargador Carlos Thompson
Flores e Dona Luíza Elvira Reis Flores, filha do Barão de Camaquã, um dos comandantes militares da Guerra do Paraguai; pelo lado materno, o Dr. João Pereira da Silva Borges Fortes, político e magistrado no Império, e Dona Ofélia Abbott Borges Fortes, irmã do ex-Ministro da República e ex-governador, Dr. Fernando Abbott.

O Ministro Carlos Thompson Flores é descendente de algumas das mais ilustres e antigas famílias do Brasil que forneceram ao nosso país políticos do mais alto relevo, como o Marechal Hermes Rodrigues da Fonseca, Presidente da República, diplomatas como o embaixador Carlos Martins Thompson Flores, médicos como o Conselheiro do Império Dr. Jonathas Abbott, considerado por muitos o maior luminar da ciência médica brasileira no século XIX.

Destacam-se, ainda, o Coronel Thomaz Thompson Flores, herói da Guerra de Canudos, cujos feitos são relatados por Euclides da Cunha na obra clássica "Os Sertões"; o Ministro Francisco Thompson Flores, Ministro do Tribunal de Contas da União que, em 1937, como relator das contas do Presidente Getúlio Vargas, levou a Corte de Contas a manifestar-se pela rejeição das contas do Presidente da República, em decisão sem precedentes na história daquele Tribunal. 
É descendente direto do bandeirante Raposo Tavares, um dos fundadores do Brasil, e de Dionísio Rodrigues Mendes, um dos primeiros povoadores do Rio Grande do Sul, cuja fazenda, em meados do século XVIII, situava-se em terras onde hoje se localiza o Município de Porto Alegre.

Uma das fazendas de seu bisavô, o Dr. João Pereira da Silva Borges Fortes, notável político do segundo reinado, hospedou o Imperador $\mathrm{D}$. Pedro II e toda a sua comitiva, no ano de 1865, em São Gabriel, quando de sua visita à Província de São Pedro.

Corre em suas veias o nobre sangue da família Leme, de São Paulo, que deu ao Brasil homens como o Cardeal D. Sebastião Leme, que desempenhou papel decisivo para o favorável desfecho da Revolução de 1930, ao convencer o Presidente deposto Washington Luís Pereira de Sousa a partir para o exílio.

São, ainda, seus primos o Almirante Diogo Borges Fortes, Ministro e Presidente do Superior Tribunal Militar, o General Carlos Flores de Paiva Chaves, o primeiro militar brasileiro a comandar tropas da ONU - comandou a Faixa de Gaza nos anos cinquenta -, o Almirante
Joaquim Flores do Rêgo Monteiro, formado em Engenharia Naval na Inglaterra e um dos pioneiros no país nessa importante modalidade de engenharia e o Embaixador Francisco Thompson Flores, um dos responsáveis pela criação e instalação do Mercosul, quando embaixador em Buenos Aires.

Essas, em apertada síntese, são as origens familiares de Carlos Thompson Flores.

O homem, disse-o Antonio Joaquim Ribas, em sua biografia de Campos Salles, é um ser sucessivo, cuja alma contém, algumas vezes, as virtudes de cem gerações. ${ }^{3}$

Como nos minerais e vegetais, prossegue o notável biógrafo, a natureza elabora, longa e surdamente, as suas obras-primas na humanidade.

Eis por que assinalamos que nos seus antepassados já se revelavam as altas virtudes que, aperfeiçoadas pelo estudo e meditação, destinaramno às mais elevadas posições na administração da nossa Nação.

A l'origine d'une vocation, recorda Roger Martín Du Gard, il y a presque toujours un exemple.

No exemplo de seus ancestrais, colheu a inspiração e o estímulo que lhe serviram de motivação na escolha

3 Ribas, Antonio J., In: Campos Salles - Perfil Biográfico, Rio de Janeiro, 1896, p. 536. 
de sua vocação, a magistratura, cujo exercício consumiu toda a sua existência.

A rigor, parodiando Ruy Barbosa, dele se pode afirmar: Juiz, sempre Juiz, apenas Juiz.

Fez o curso primário no Colégio Público Elementar "14 de Julho", na cidade de Montenegro. O ginásio no Colégio Estadual Júlio de Castilhos, escola modelar na época, em Porto Alegre.

Concluído o curso secundário, matricula-se na tradicional Faculdade de Direito de Porto Alegre, fụndada por seu avô, o Desembargador Carlos Thompson Flores, em 1900.

Forma-se com distinção como integrante da turma de 1933, tendo colado grau em solenidade especial realizada no gabinete do Diretor, eis que já era, a esse tempo, Juiz Distrital de Herval do Sul, termo da Comarca de Jaguarão.

Em 1938, após aprovação em concurso público, é nomeado Juiz de Direito da Comarca de Santa Vitória do Palmar. Daí passou, mediante remoção, para a Comarca de Rosário do Sul. Posteriormente, foi promovido, sucessivamente, para as Comarcas de Montenegro, de $2^{\mathrm{a}}$ entrância, e Livramento, de $3^{\mathrm{a}}$ entrância.

Em 1951, é promovido para a Capital e, posteriormente, designado para a Vara dos Feitos da Fazenda Pública, desaguadouro dos grandes nomes da magistratura rio-grandense.
Em 13 de abril de 1953, é convocado para substituir o Desembargador Homero Martins Batista sendo, logo a seguir, em 03 de junho, promovido a Desembargador do Tribunal de Justiça, com 42 anos de idade, o mais moço na época.

Todas as suas promoções na carreira sempre foram movidas pelo impulso nobilitante do merecimento, num claro reconhecimento das suas marcantes qualidades de julgador.

No Tribunal de Justiça, foi eleito para o cargo de Corregedor-Geral da Justiça, tendo-o exercido por dois períodos consecutivos, deixando ditas funções para compor a $4^{\mathrm{a}}$ Câmara Cível, em março de 1960.

No Tribunal Regional Eleitoral, exerceu os cargos de Vice-Presidente e Presidente.

A sua atividade, porém, não se restringiu à magistratura.

Realmente, durante muitos anos professou a cadeira de Processo Civil no Curso de Formação de Magistrados mantido pela Associação dos Juízes do Rio Grande do Sul.

Designado mediante eleição, representou o Tribunal de Justiça no Congresso de Juristas em comemoração do Centenário de Clóvis Beviláqua, realizado na cidade de Fortaleza, em 1958.

Da mesma forma, representou o Tribunal de Justiça perante a III Conferência Nacional de Desembargadores, realizada em 1964, na cidade 
do Rio de Janeiro, quando foi distinguido por seus pares para presidir uma das quatro comissões - a de processo civil -, escolhendo como seu secretário o Professor Alfredo Buzaid.

Essa comissão debateu a fundo o anteprojeto do Código de Processo Civil, sendo que várias de suas sugestões foram incorporadas ao mencionado projeto de codificação.

É eleito Vice-Presidente do Tribunal no período de 1964-1965 e, posteriormente, Presidente no biênio 1966-1968.

Os seus elevados méritos levaram o Tribunal, por unanimidade, a quebrar o critério da antiguidade e elegê-lo Presidente da Corte antes de chegar a sua vez pelo rodízio tradicional, pois reconheceram os seus integrantes que o Desembargador Thompson Flores era, na oportunidade, a pessoa certa para promover as reformas que o Judiciário gaúcho necessitava.

Com efeito, na chefia do Poder Judiciário Estadual empenhou-se decididamente na superação dos entraves que há décadas emperravam o judiciário gaúcho com as seguintes medidas: criou a Revista de Jurisprudência do Tribunal; instituiu os boletins de jurisprudência da Corte distribuídos quinzenalmente aos desembargadores, providência essa que, posteriormente, como Presidente do Supremo Tribunal Federal, difundiu na Suprema Corte e em todos os Tribunais do país; promoveu a elaboração de um novo Código de Organização Judiciária; encaminhou sugestões à reforma da Constituição Estadual, em atendimento à adaptação à Constituição Federal de 1967; dinamizou e concluiu as obras do Palácio da Justiça, paralisadas há mais de dez anos; garantiu a ampliação dos quadros de pessoal da Secretaria do Tribunal, por meio da Lei $n^{\circ} 5.668 / 67$; criou a assessoria de imprensa do Tribunal, iniciativa pioneira para divulgar à sociedade as atividades do Judiciário, tornando-o mais conhecido da população; procurou as faculdades de direito dialogando diretamente com os estudantes para sensibilizá-los no ingresso à magistratura.

Prestes a cumprir o seu mandato, é nomeado pelo Presidente Costa e Silva ministro do Supremo Tribunal Federal, na vaga do Ministro Prado Kelly, por decreto de 16 de fevereiro de 1968.

A sua posse deu-se em 14 de março, nela comparecendo o que havia de mais representativo da cultura jurídica e do cenário político do Rio Grande do Sul, fruto da fama do juiz excepcional que, em seu estado de origem, conquistara o respeito e admiração de seus coestaduanos face às suas qualidades de inteligência, independência, cultura, honradez e trabalho.

No Supremo Tribunal Federal, permaneceu cerca de treze anos, 
ratificando o alto conceito de que viera precedido.

Seria dar incontável extensão ao presente texto se, porventura, se quisesse examinar em pormenores o brilho da judicatura do Ministro Thompson Flores na Suprema Corte.

Os seus votos, em geral, não eram muito extensos, mas profundos, valendo-se da melhor doutrina, desvendando o âmago da causa numa síntese admirável de exatidão e brilho.

Em 07 de agosto de 1980, julgando o RE no 88.407-RJ (Pleno), versando a responsabilidade civil do transportador na hipótese de assalto ao passageiro, proferiu voto que bem retrata sua técnica de julgar, verbis:

"O SR. MINISTRO CARLOS THOMPSON FLORES (RELATOR):

- Conheço do recurso e lhe dou provimento para restabelecer a sentença de fls. 65/66, excluindo, porém, a indenização pelo dano moral, e, no pertinente aos honorários de advogado, reduzi-lo a $15 \%$, nos termos do art. 11 da Lei 1.050/60.

2. Decidindo como decidiu o acórdão recorrido que, à transportadora, não cabia responsabilidade porque ocorrera "fator impediente do cumprimento do dever de incolumidade do passageiro acrescido de sua culpa" face aos fatos que se oferecem certos, penso que o decisório não só denegou vigência ao art. 17 , e seus incisos $1^{\circ}$ e $2^{\circ}$, do Dec. Legislativo 2.681/912, como dissentiu do enunciado na S. 187 e julgado, desta Corte, pro- ferido no $R E \mathrm{n}^{\mathrm{o}} 73.294,2^{\mathrm{a}}$ Turma, de 03.12 .73 (R.T.J. 70/720/1), cuja ementa dispõe:

'Responsabilidade civil. Transporte urbano de passageiros. Ao elidir a responsabilidade do transportador, por não ser estranho à exploração da atividade, o fato de terceiro, motorista de outro veículo, após discussão provocada pelo condutor do coletivo sobre questiúnculas de trânsito, disparar sua arma contra este e atingir o passageiro. Dissídio com as Súmulas 187 e 341.

Recurso extraordinário conhecido e provido'

Justifica-se, dessarte, o conhecimento do recurso.

E cabe provê-lo.

Os fatos se oferecem certos, como reconheceram as partes e os julgados de primeiro e segundo graus.

Apenas no pertinente à sua qualificação é que dissentiram.

$E$, fazendo como fez o aresto impugnado, não só deixou de aplicar a regra adequada na sua conceituação própria (art 17, e seus incisos $1^{\circ}$ e $2^{\circ}$ ) como discrepou do correto conceito jurídico que atribuíram os padrões aludidos.

Por isso, o restabelecimento parcial da sentença do nobre Juiz Antonio de Oliveira Tavares Paes que, em precisa síntese, fez incensurável adequação dos fatos à lei, ao afirmar, fls. $65 \mathrm{v} / 66$ :

'Nenhum valor me parece ter a alegação constante da contestação, no que diz respeito à existência 
de força maior ou de caso fortuito a descaracterizar a obrigação indenizatória. Está provado que a existência de assaltos coletivos, na região em que a firma ré explora sua atividade lucrativa, alança índices alarmantes $e$ os autos dão bem uma notícia disso (fls. 18), além de se tratar de fato público e notório, que independe de prova. Ora, sendo um fato que já se integrou nà diuturnidade da vida de quem habita aquela região, a ocorrência desses assaltos não pode ser considerada como fato imprevisível a caracterizar a fortuidade de sua verificação. Parece-me irrespondível a douta argumentação neste sentido expendida pelas autoras, na réplica de fls. 51/60, que se constitui em verdadeira aula sobre responsabilidade civil.

Acresce notar que a ré alegou que o próprio marido e o pai das autoras foi o único responsável pelo evento, pois, foi ele quem deu início ao tiroteio e, assim, teria dado início a um outro processo causal, que estaria a descaracterizar a responsabilidade decorrente da garantia de incolumidade devida aos passageiros pela transportadora.

Tal argumento, se bem que impressionante à primeira vista, não resiste a um exame mais profundo, pois, quando da interferência da vítima, já se caracterizara o inadimplemento à garantia de incolumidade, pois, não apenas um passageiro, mas, todos se achavam submetidos à mira das armas dos meliantes, pelo que evidenciada a falta de precaução da ré em evitar o ocorrido.

Não é resultado lesivo que caracteriza $o$ inadimplemento da obrigação da transportadora de assegurar ao passageiro sua incolumidade física, mas sim a simples criação in concreto da possibilidade de sua verificação. No caso, o resultado apenas determina a incidência de uma obrigação secundária, que diz com a reparação dos danos sofridos.

Se o passageiro for submetido a um risco concreto de lesão e esta não vier a se concretizar, não há como se negar o inadimplemento da obrigação de garantia de incolumidade, no entanto, não há que se falar em indenização, pois, esta decorre do dano e o mesmo não se verificou.

No caso dos autos, o inadimplemento da obrigação de garantia de incolumidade se verificou com a ocorrência do assalto e as lesões sofridas pela vítima, que vieram a ocasionar sua morte, nada mais são do que um desdobramento desse fato inicialmente imputável à ré. Não importa que os demais passageiros não tenham sofrido danos, pois, o que caracteriza a obrigação é a conjugação do inadimplemento com a verificação da lesão, e, desde que verificada tal conjugação, é inarredável a responsabilidade indenitária'

4. Nem poderia a demanda ter outro desfecho.

O documento que se refere a sentença, certidão expedida pela Delegacia de 
Polícia de São João de Meriti, fls. $18 / 19$, de criminalidade inferior à de Caxias, onde ocorreram os fatos, bem como de Nova Iguaçu, revelou que no ano de 1974, só na referida Delegacia, foram registrados 228 assaltos a coletivos, o que representa uma média de quase um por dia.

Dita média, seria maior na cidade onde se verificou.

Em verdade, é fato, mais que notório, tais ocorrências na Baixada Fluminense, como bem acentuara o magistrado.

Apreciando acontecimento que se repete no trânsito, o qual pela conduta de terceiro originou dano a passageiro de ônibus, acentuou o eminente Ministro Xavier de Albuquerque, relator do padrão referido:

'Tomados os fatos na versão do próprio acórdão, não vejo como the endossar a conclusão. Discussões desse gênero chegam a ser rotina no trânsito do Rio de Janeiro, felizmente não no sendo desfechos como o que essa teve. Mas tais desfechos também não chegam, por desgraça, a ser raros. A imprensa se ocupa frequentemente com episódios análogos, que sociólogos, psicólogos e médicos procuram interpretar em estudos sérios e conhecidos.

$\mathrm{O}$ fato do terceiro, que deu causa aos danos sofridos pelo recorrente, não pode considerar-se estranho à exploração do transporte urbano de pessoas numa cidade como o Rio de Janeiro, a ponto de equiparar-se ao caso fortuito ou à forma maior.
Principalmente quando, como reconhece o Tribunal a quo, deuthe ensejo, não importa que sem proporção, a discussão, provocada pelo preposto da transportadora.' (RTJ 70/721).

Em tais condições não ocorrem, a meu ver, quaisquer dos pressupostos capazes de afastar a responsabilidade do recorrido, ou seja, fato de terceiro ou culpa exclusiva, da vítima.

Com efeito.

No campo da responsabilidade civil nos transportes coletivos de passageiros, a Jurisprudência do S.T.F. tem sido sempre sensível à realidade, como também ocorre em países outros, especialmente, França e Itália.

Em princípio, e desde 1920, passou a aplicar o vetusto Dec. Legislativo $\mathrm{n}^{\circ}$ 2.681/912 ao transporte através dos bondes.

Após, ampliou-se aos ônibus, e chegou até às lotações como o admitiu a Eg. $3^{\mathrm{a}}$ Turma ao julgar o RE $\mathrm{n}^{\circ}$ 59.966, em 11.04.69 (RTJ 55/429)

Intercorrentemente, quebrando a rigidez do Código Civil, art. 1.523, admitiu a presunção de responsabilidade do preponente.

O caso, assim, deve ser considerado ante a dolorosa realidade do que sucede e se agrava, como é notório, nas grandes capitais e aqui nas cidades que integram a chamada 'Baixada Fluminense' onde ocorreu o evento.

Atento às circunstâncias que o rodearam, não há como falar em "fator 
impediente no cumprimento do dever" capaz de elidir a responsabilidade pelo fato, de parte do transportador, como aceitou o acórdão.

É que, por disposição expressa da lei, art. 17, segunda parte, sua culpa é "sempre presumida", ressalvadas as duas hipóteses de seus incisos $1^{\circ} \mathrm{e} 2^{\circ}$, fortuito ou força maior, e, bem assim, culpa exclusiva da vítima.

Precisou o Código Civil, no seu art. 1.058, a conceituação dos dois primeiros.

In casu, cuida-se do segundo, o fato de terceiro, o qual, em verdade, não seria excludente de sua responsabilidade, apenas daria direito de regresso contra o causador do dano, nos termos do art. 19 da citada lei especial, como sentido que se lhe atribuiu a Súmula 187, ou seja, compreensivamente, como já acentuava Aguiar Dias fundado no ensinamento dos Tribunais (Da Responsabilidade Civil, vol. 1, 1979, p. 231).

É mister, porém, como acentua:

'Assim, qualquer que seja o fato de terceiro, desde que não seja estranho à exploração, isto é, desde que represente risco envolvido na cláusula de incolumidade, a responsabilidade do transportador é iniludível, criando, entretanto, o direito de regresso em favor do transportador sem culpa no desastre.'

É esta, ademais, a lição dos doutrinadores.

Sucede, porém que, na espécie em exame, de fortuito, não se trata de que o fato não seja estranho à atividade da empresa que se dispõe a explorar o transporte de passageiros, na área já referida e, cujos riscos, contra ela mesma, em sua arrecadação, e notadamente na incolumidade de seus passageiros, eram previsíveis, e assim, quando não, de todo evitáveis, pelo menos reduzíveis ou atenuados.

Todavia, apesar de tudo, não comprovou, como lhe impendia, qualquer providência pertinente, que tenha tomado, seja para si mesma, diretamente, seja perante as autoridades policiais para as providências que lhe coubessem tomar.

E, tanto era de seu conhecimento o risco dos assaltos, de resto, de manifesta notoriedade, que atribuiu a guardas seus a segurança de seus escritórios e locais de arrecadação da "féria", como esclareceu a prova.

As medidas de segurança são, de resto, quase que habituais, como ocorre com os veículos que transportam valores, acompanhados de pessoal especializado e fortemente armado.

Nem se alegue que, com a concessão para exploração do transporte $\mathrm{e}$ pagamento dos tributos estaria isenta das medidas de segurança.

Não nas condições conhecidas e, apesar delas, expor-se aos azares em comentário.

Demais, a disciplina interna, conexa com a segurança e bem-estar dos passageiros, eram de sua integral responsabilidade, apenas sujeita à limitada fiscalização do Poder Público. A presença de guardas seus 
pelo menos à noite era providência que se impunha, ao menos para prevenir ou reduzir os riscos. Ainda aqui, omitiu-se.

Evidencia-se, assim, a ausência absoluta de quaisquer das causas elisivas da responsabilidade, força maior ou fortuito, no último se inserindo, como acontece, na legislação de outros países, $o$ ato de terceiro.

Pouco importa que seja ele até criminoso, como reconheceu a $\mathrm{E}$. Primeira Turma ao julgar o RE 80.416, em 04.10.77 (RTJ 86/837), quando a passageira vitimada, foi passível da ação de terceiro, um ladrão, ao arrebatar-lhe uma corrente de valor.

De outra parte, bem analisou a sentença a conduta da vítima, a qual posto que, também culposa, o que se admite, apenas, para argumentar, sem consentir, não seria exclusiva como o requer o inciso $2^{\circ}$ do citado art. 17 , sem o alcance pois, para elidir a responsabilidade por sua morte, segundo orientação desta Corte.

Por fim, quero referir-me à Jurisprudência dos Tribunais estrangeiros. Da busca procedida, pouco se obteve.

René Rodière, professor de Direito de Transportes da Faculdade de Direito de Paris, em seu Droit des transportes terrestres et aériens 1973, ps. $358 / 9$, indica julgados alusivos a transporte coletivo nos quais seus passageiros teriam sofrido danos por atos de sabotagem.

Das decisões tomadas, extraiu ele, entre outras, estas afirmações:

'... èlle (SNCF) est responsable d'un attentat commis sans qu'elle ait pu prouver que ses agentes n'y ont pas participé.'

Por último, cabe considerar a indenização pelo dano moral.

Deu-a a sentença sem maior fundamentação. Todavia, a Jurisprudência do S.T.F, em caso como o dos autos, não o tem consagrado (ERE 53:404, Relator Min. Adalício Nogueira, in RTJ 42/378, RE 71.465, Rel. Min. Eloy da Rocha, in RTJ 65/400; RE 59.358, Rel. Min. Victor Nunes, in RTJ 47/276 e RE 84.718, do qual fui relator, in RTJ 86/560).

E, quanto aos honorários, porque goza o autor do benefício da assistência judiciária, fixei-os de acordo com a respectiva lei especial.

No mais, reporto-me aos fundamentos do parecer da douta ProcuradoriaGeral da República, e da sentença restabelecida.

É como voto."

Da mesma forma, questão singular foi enfrentada pelo Presidente Thompson Flores ao deferir medida

4 In: RTJ, v. 96/1205-9. 
cautelar no Pedido de Avocação $\mathrm{n}^{\circ} 1 /$ SC, julgado pelo Plenário, em 14 de dezembro de 1978.

O seu voto é do seguinte teor, verbis:

"Em 11 do próximo passado, quando o Tribunal se encontrava em férias, requereu $o$ Dr. Procurador-Geral da República a concessão de medida cautelar em pedido de avocação, fundada no art. 119, I, letras o, e p, da Constituição, na redação que lhes atribuiu a Emenda $n^{\circ} 7 / 77$.

Fê-lo através do petitório de fls. $2 / 12$, cuja leitura sou levado a fazer para integral compreensão da controvérsia (ler).

Veio ela instruída com farta documentação, constante de manifestação dos Srs. Ministros dos Transportes e das Relações Exteriores, fls. 13/14 e 172, acompanhada aquela de vasta correspondência recebida da SUNAMAN e da SYNDARMA, além de recortes de vários periódicos nacionais e um do exterior, alusivos ao assunto.

Outrossim, vieram com a pretensão documentos extraídos dos autos da ação, especialmente na fase de cognição, sentença, acórdãos do Tribunal Federal de Recursos e do Supremo Tribunal Federal; e na de execução, o laudo pericial, a sentença de liquidação, a apelação interposta e autos de penhora de dinheiro (depósitos) e de imóveis, na cidade do Rio de Janeiro.
Os efeitos da execução provisória, face à apelação interposta, sem exigência de caução, ficaram assim resumidos pela SUNAMAN e endossados pelo Senhor Ministro dos Transportes, ao consignar, verbis, fls. 15/7:

"Tal procedimento, a nosso ver, caso não venha a ser sustado de imediato, terá efeitos desastrosos para a política econômica do Governo e especialmente para a de marinha mercante, afetando a vários setores da atividade pelos motivos que seguem:

1) o nosso intercâmbio comercial com o exterior será fatalmente afetado, uma vez que empresas de navegação nacionais e estrangeiras cancelarão suas escalas nos portos envolvidos;

2) haverá redução da receita dos portos nos quais essas empresas deixarem de frequentar;

3) acarretará falta de cumprimento, pela bandeira brasileira, de seus compromissos internacionais de transportes decorrentes de acordos bilaterais e, também, nos acordos de rateio de fretes, no caso de diminuírem a sua participação no transporte marítimo, o que, certamente, acontecerá;

4) os programas de exportação do Governo serão seriamente prejudicados, principalmente os daquelas mercadorias para as quais já tenham sido equacionados seus programas de transporte marítimo;

5) as importações de materiais e equipamentos indispensáveis ao 
desenvolvimento do País também serão prejudicadas;

6) com o enfraquecimento da política de marinha mercante teremos reduzida a receita de divisas produzida pelos fretes por ela gerados;

Por outro lado, já temos notícia de que grande número de embarcações do Norte da Europa já manifestaram sua intenção de não embarcarem suas cargas nos navios da Empresa de Navegação Aliança S/A, receosos de que os navios da mesma venham a ser objeto de arresto, ficando paralisados nos portos e causandolhes vultosos prejuízos.

Assim, estando a este Órgão afeta a execução da política da marinha mercante, vimos além de encaminhar a exposição e os documentos anexos, oriundos do SYNDARMA, manifestar a nossa preocupação pela gravidade da situação criada, que poderá estender-se a todos os portos do País, e cujas consequências são imprevisíveis, principalmente, para o Setor de transporte marítimo"

Do mediato exame da documentação convenci-me da ocorrência, em princípio, dos pressupostos que justificam a avocatória, e, ainda, que, para sua real eficácia, impendia a concessão da medida cautelar, visando sustar, de pronto, os efeitos produzidos pela sentença em fase concreta de execução.

Quanto ao procedimento, coincide ele com a conceituação que lhe atribuiu esta Corte no Diagnóstico da Reforma do Poder Judiciário (Reforma do Poder Judiciário, Diagnóstico, ps. 37/8, ns 41/2).

Seus pressupostos foram transplantados para a Constituição, através da Emenda $n^{\circ} 7 / 77$, na redação do art. 119, I, o.

É certo que o Supremo Tribunal Federal ainda não disciplinou seu processamento.

$\mathrm{O}$ projeto da respectiva Emenda Regimental, elaborado pela Comissão, está em fase de estudo perante o Plenário.

A meu ver, tal omissão não obsta a aplicação imediata da norma constitucional vigente, adotado $\mathrm{o}$ processo similar da Representação, ao qual se referem os arts. $174 \mathrm{e}$ seguintes do Regimento Interno, no que couber. Permito-me aqui pequena digressão.

Ao advir a primeira lei que disciplinou o processo de declaração de inconstitucionalidade em tese, prevista pela Constituição de 1946, e que ao que me parece, 2.175 , expedida ao tempo do governo Café Filho, adotou em seu procedimento as normas que regulavam o mandado de segurança.

E por duas vezes pelo menos esta Corte concedeu em tais feitos medidas cautelares, invocando para fazê-lo as disposições da citada lei $n^{\circ} 1.533 / 51$. Refiro-me às Representações n $\mathrm{n}^{\circ} 466 \mathrm{e}$ 467 , das quais foram respectivamente Relatores os eminentes Ministros Ari Franco e Victor Nunes (DJ de 16.11.61, Ap. 209, pág. 621 
e seguinte; e RTJ 23, pág. 1 e seguintes). Para o caso, a questão se faz mais singela, pois o art. 175 do Regimento Interno alude à medida reportando-se ao art. 22 , IV.

E assim decidiu este Plenário ao apreciar a Representação $\mathrm{n}^{\circ} 933$ da qual fui Relator (RTJ 76/342).

As dúvidas então suscitadas desapareceram ante a Emenda Constitucional $\mathrm{n}^{\circ} 7 / 77$, como passou a dispor o art. $119, \mathrm{I}$, letras o e p.

Certo que a decisão caberia ao Plenário.

Estando, porém, em férias a Corte, dita atribuição ficou a cargo do Presidente, como dispõe o art. 14, VIII, do citado Regimento, sujeitando sua decisão ao referendum do Plenário. $E$ isto porque a medida, caso não estivesse em férias o Plenário, caberia ao Relator, face à urgência, mas ad referendum do Órgão.

No que pertine ao merecimento, a documentação convence, seja justificando a avocação, seja a medida cautelar, demonstrando decorrer do decisório impugnado, já em fase de concreta execução, imediato perigo de grave lesão à segurança, e, especialmente, das finanças públicas.

Ademais, complexa execução processa-se por simples, arbitramento, cujo laudo severamente atacado pelas partes, estima os prejuízos na elevada cifra de Cr\$ 59.919.150,05.

E, posto provisória a execução, face à apelação interposta, teve ela curso, sem qualquer caução, contrariando o disposto no art. 585, I, do Código de Processo Civil.

Por último, é de anotar-se que já se encontra em tramitação perante esta Corte, ação visando rescindir o acórdão proferido na fase final de cognição da causa. Refiro-me à A. R. $\mathrm{n}^{\circ} 1.040$, a qual tem como Relator o eminente Ministro Soarez Muñoz.

Por fim, a concessão de liminar, cingiu-se a sustar o prosseguimento da execução.

E o despacho por mim prolatado é o seguinte, fls. 216 (verso):

"A. Conheço do pedido, como incidente do procedimento a que se refere o art. $119, \mathrm{I}, \mathrm{o}$, da Constituição, na redação da Emenda $n^{\circ} 7 / 77$. E o defiro, ad referendum do Plenário, a medida cautelar postulada pelo Dr. Procurador-Geral da República, suspendendo os efeitos da sentença de liquidação, proferida nos autos da Ação de Indenização a que se refere a presente petição a fl. 11 .

E assim o faço, nos termos do Regimento Interno, reconhecendo decorrer do decisório impugnado imediato perigo de grave lesão à segurança e, especialmente, das finanças públicas.

E assim o concluo do exame dos documentos que instruem o pedido, notadamente da judiciosa fundamentação aduzida pela "SYNDARMA" ao Ministro dos Transportes e por ele acolhida; e, bem assim, das considerações aduzidas pelo Ministro das 
Relações Exteriores, ao considerar, como aquele, o elenco de consequências emergentes do veredicto impugnado, em face de sua ruinosa execução, afetando as próprias relações internacionais do Brasil e o seu comércio marítimo com Nações irmãs.

A tudo se ajuntem os comentários desfavoráveis de vários periódicos nacionais, e ainda, do Lloyd's List, de Londres, edição de 29.12.77, como se verifica da documentação anexa.

Expeça-se, imediatamente, via "telex", nos termos da minuta anexa, devidamente por mim autenticada, comunicação ao Dr. Juiz Federal, Secção Judiciária do Estado de Santa Catarina, com jurisdição no feito originário, para que faça cumprir esta determinação, acusando $o$ recebimento da comunicação e dando pronta ciência das providências tomadas. Outrossim, expeça-se ao Magistrado ofício, acompanhado da cópia desta e respectivo despacho para que, em quinze dias, preste as informações que entender de direito".

Esclareço que sua determinação foi cumprida, segundo comunicação de fls., e que a esta altura as informações solicitadas já se encontram nos autos. Trago agora, na forma regimental, art. 14, VIII, ao referendum do Egrégio
Tribunal, o despacho em questão, antes de fazer sua distribuição.

Pareceu-me que esta seria a ordem lógica, pois, responsável pela decisão, poderia, creio, proporcionar melhores esclarecimentos de meu livre convencimento ao prolatá-la.

Acentuo, por último, que no processamento procurei orientar-me pelo Projeto da Emenda Regimental referente ao pedido de avocação, na parte já aprovada.

É o relatório, o qual se tornou um tanto extenso pela originalidade do tema" (fls. 564 a 570, $2^{\circ}$ volume)." 5

De outra feita, o Recurso Extraordinário Eleitoral $\mathrm{n}^{\circ}$ 90.332-SP, julgado pelo plenário, em que figurava como parte o então candidato ao Senado Fernando Henrique Cardoso, posteriormente Presidente da República, enfrentou relevantíssima questão constitucional e de direito eleitoral, na época, acerca do prazo da sanção prevista no Ato Institucional $n^{\circ} 5 / 68$ e a sua respectiva projeção na inelegibilidade, interpretando o art. 154 da CF de 1967, na redação da $\mathrm{EC} \mathrm{n}^{\circ} 1 / 69$.

O Ministro Thompson Flores, Presidente do Supremo Tribunal Federal, profere voto - amostra de como julgava - nestes termos, verbis: 
"O Sr. Ministro Thompson Flores: (Presidente) - A natureza do recurso leva-me a votar. É o que passo a fazer.

Adianto, desde já, que estou de pleno acordo com o eminente Relator.

Penso que S. Exa. examinou a controvérsia com precisão lógica e deu-lhe solução juridicamente fundada, em brilhante argumentação, ornada, por vezes, com lances de elegância estilística.

Convinha mesmo apreciar as duas correntes que formaram a maioria do T.S.E., originando o decisório.

Aquela que o situou nas lindes da L.C. $\mathrm{n}^{\circ} 5 / 70$, cuja interpretação bastou para dirimir ali o litígio, por certo, tornou quase inviável o recurso extraordinário, circunscrito, quando se trata de julgado daquela Corte Eleitoral, em contrariedade à Constituição.

E, a toda evidência, sua afronta em si, não importa na prática de igual pecado contra a Carta Maior, a menos que, no particular, seja ela um decalque desta. $\mathrm{O}$ desrespeito, pois, não seria em tal hipótese, à Lei Complementar, mas à própria Constituição.

Mas isto não ocorreu, como bem demonstraram o despacho presidencial e o eminente Relator.

Procura o douto recorrente invocar em seu prol precedente em Representação de Goiás, quando se teria enfocado a L.C. $n^{\circ}$ 10/74.

O símile não oferece, data venia, o devido préstimo, dado que, face a seus termos, o que o Tribunal reconheceu, então, é que a própria criação do município goiano afrontava o art. 14 da Constituição.

A relevância da questão, porém, se apresentou no pertinente a outra corrente que se formou na Corte Eleitoral e que somou a maioria, calcada nos votos dos eminentes Ministros Leitão de Abreu e, especialmente, seu Presidente, o já saudoso Rodrigues Alckmin.

Considerou ela, diversamente da outra, o prazo de inelegibilidade, estimando-o em dois anos, fundada no art. 154 da própria Constituição, e por isso já então decorrido.

Penso que, assim procedendo, de forma alguma, afrontou o decisório os arts. $6^{\circ}$ e 151 , ambos da Carta Maior, como se sustenta.

Realmente. O que fez a maioria vencedora ao estimar o prazo? Penso que supriu exigência da lei, buscando, em fonte própria, sua inspiração, o art. 154 do Estatuto Máximo.

Aplicou, como lembraram o Ministro Cunha Peixoto, o art. $4^{\circ}$, da L.I.C.C., e o Ministro Xavier de Albuquerque, $o$ art. 126 do C.P.C.

E assim o faz o julgador vezes muitas, realizando um dos mais nobres e importantes de seus deveres suprir as lacunas da lei, revelando-a, dando-lhe o seu legítimo sentido e real alcance.

Faz instantes, em sua sustentação oral, invocava da tribuna o advogado do recorrido o R.E. $\mathrm{n}^{\mathrm{o}}$ 71.293, o qual foi relator o eminente Ministro Amaral Santos. 
Ali, como aqui, discutia-se matéria de inelegibilidade. Fora eu o relator do acórdão, proferido pelo Egrégio Tribunal Superior Eleitoral, chamado a substituir o eminente e saudoso Ministro Barros Monteiro, impedido.

O T.R.E. de São Paulo admitira que o prazo máximo da suspensão dos direitos políticos admitido nos Atos Institucionais era 10 anos.

A lei não o dissera, mas o Tribunal local, revelando-a, reconheceu.

O T.S.E. não conheceu do recurso, como que endossando a tese.

$\mathrm{Na}$ discussão nesta Corte, que não se estatuíra inelegibilidade perpétua, como admitiam que $o$ aresto o fizesse, os eminentes Ministros Bilac Pinto e Adauto Cardoso.

O que admitiu o S.T.F., então, é que ela findaria aos 10 anos.

Vê-se assim que ali se fixou um limite máximo.

Aqui o T.S.E. admitiu o mínimo para o caso. E friso, para o caso, porque não proferiu ele decisão normativa, o que estaria ao seu alcance, porque, para que ocorresse a normatividade, outros pressupostos se fariam mister, como é elementar.

Antes, limitou-se a apreciar a relação discutida. Ateve-se a ela. E como reconheceu omissa a lei, aplicou norma legal para supri-la.

Mais, inspirou-se, para solver a controvérsia, de norma política do próprio Estatuto Político, a Constituição, no seu art. 154, o qual, a par do prazo máximo, 10 anos, fixou também o mínimo, 2.
E, sem ares de arbítrio, mas em cotejo com a hipótese que julgava, ateve-se ao prazo ínfimo.

Legislou a respeito, afetando o princípio insculpido no art. $6^{\circ}$ ou naquele previsto no art. 151, ambos, da citada Carta, como sustenta o recorrente?

Seguramente, respondo pela negativa.

Ao contrário, operou laboriosa construção jurídica, suprindo, com material próprio, omissão legislativa para bem e politicamente solver controvérsia desse gênero.

Manifesto é que não poderia a irresignação contra tal procedimento merecer do S.T.F. sua acolhida, máxime ante o disposto no art. 139 da Constituição.

A regra que nele se contém é a irrecorribilidade das decisões do T.S.E. A exceção está nas duas ressalvas que introduz: H.C. denegado e decisão que contrarie a própria Constituição. Há ligeira similitude entre o citado art. 139 e o art. 143, posto que, a meu ver, aquele seja mais restrito, mais preciso e incisivo.

Tudo está a mostrar que somente quando o acórdão do T.S.E. contrarie a Constituição cabe o extraordinário, afora as hipóteses dos Habeas Corpus denegados.

E não seria possível admitir que inocorresse na grave falta o decisório impugnado que antes de contrariá-la, relevou-a, buscou, em seus próprios princípios, meios para suprir lacuna de norma política. 
Mantendo, exerce o S.T.F seu alto papel político, interpretando a Constituição.

Em conclusão, com a vênia do voto do eminente Ministro Cordeiro Guerra, não conheço, também, do recurso.

É o meu voto."

Longo seria, nesse momento, arrolar e comentar os votos e intervenções mais importantes proferidos pelo Ministro Thompson Flores, reveladores de sua vivência, cultura e prudência, marcas registradas de um grande juiz.

Já foi dito, e não constitui originalidade, que a jurisprudência não é mais do que a luta do bom senso contra a cegueira dos princípios absolutos.

Os exageros são perniciosos.

O bom magistrado não se define em fórmula matemática, razão pela qual o ato de julgar constitui acima de tudo uma arte.

Nesse sentido, a velha mas sempre nova lição do Juiz Ransson, verbis:

"Si la connaissance du droit est une science, il est permis d'affirmer sans présomption que la manière de l'appliquer constitue veritablement un art."

Cabe ao juiz ir dizendo, em face dos fluxos e refluxos da vida em sociedade, onde acabam os direitos e começam os abusos, até que ponto o expandir-se de cada atividade não se converte em obstáculo ao conceito das demais atividades, assinalando as dissonâncias e os exageros, corrigindo, notificando, cumprindo e fazendo cumprir a Constituição e as leis do país.

Em meio século de judicatura, não houve campo da Ciência Jurídica, seja no Direito Público, seja no Direito Privado, que não a perlustrasse o Ministro Thompson Flores, com o devotamento, a competência e a proficiência que todos lhe reconhecem, fruto direto de sua reconhecida arte de julgar.

Por outro lado, convencido do papel saliente que representa nos meios de expressão do pensamento o emprego conveniente dos vocábulos, os seus pronunciamentos e votos primavam pela excelência da redação.

Seguia, no ponto, o conselho de Cícero, "utimur verbis ... iis quae

6 In: $R T J$, v. 91/338-340.

7 In: Ransson, G. Essai sur L'Art de Juger, $2^{\mathrm{a}}$ edição, A. Pedone Éditeur, Paris, 1912, p. 21. 
propria sunt" e "non erit utendum verbis iis quibus iam consuetudo nostra non utitur" $\mathrm{e}$, ainda, "moneo ut caveatis, ne exilis, ne inculta sit vestra oratio, ne vulgaris, ne obsoleta"10.

Favorecia-o o conhecimento de línguas, inclusive o latim, que lhe permitia o acesso direto à literatura especializada dos países mais adiantados, ensejando-lhe ao longo de sua vida a formação de uma qualificada e respeitável biblioteca.

Nesse ponto, importa referir a lição do notável Juiz Learned Hand quando enfatiza a necessidade da maior ilustração por parte do magistrado, notadamente quando julga questões constitucionais.

São suas palavras, verbis:

"I venture to believe that it is as important to a judge called upon to pass on a question of constitutional law, to have at least a bowing acquaintance with Acton and Maitland, with Thucydides, Gibbon and Carlyle, with Homer, Dante, Shakespeare and Milton, with Machiavelli, Montaigne and Rabelais, with Plato, Bacon, Hume and Kant, as with the books which have been specifically written on the subject. For in such matters everything turns upon the spirit in which he approaches the questions before him.

The words he must construe are empty vessels into which he can pour nearly anything he will. Men do not gather figs of thistles, nor supply institutions from judges whose outlook is limited by parish or class. They must be aware that there are before them more than verbal problems; more than final solutions cast in generalizations of universal applicability. They must be aware of the changing social tensions in every society which make it an organism; which demand new schemata of adaptation; which will disrupt it, if rigidly confined."11

$8 \mathrm{Cf}$. De. orat., III, 150: "usamos palavras que são próprias".

9 Cf. De. orat., III, 25: "não devemos usar palavras que nosso costume não mais admite".

10 Cf. De. orat., III, 10, 39: "aconselho-vos a tomar cuidado a fim de que vossa oração não seja nem pobre, nem inculta, nem vulgar, nem obsoleta".

11 In: The Spirit of Liberty - Papers and Addresses of Learned Hand, Collected by Irving Dilliard, $3^{\mathrm{a}}$ edição, Alfred A. Knopf, New York, 1974, p. 81. 
Os que conheceram e tiveram o privilégio de conviver com Carlos Thompson Flores são uníssonos sobre as virtudes e qualidades de sua personalidade, o seu cavalheirismo, a cortesia no trato com os colegas e as pessoas de modo geral.

Dele, traçou retrato fiel o saudoso Ministro Adalício Nogueira, em suas conhecidas memórias, verbis:

"Thompson Flores é uma perfeita vocação de magistrado. Talvez que lha houvesse transmitido o seu avô paterno e homônimo, Desembargador Carlos Thompson Flores. Esse pendor irresistível, ele o tem patenteado no decurso da sua longa e profícua carreira. $\mathrm{O}$ escrúpulo extremo com que ele costuma resguardar a sua vida profissional coloca-o acima de quaisquer suspeitas, que lhe possam desfigurar a atitudes.

$\mathrm{Na}$ pequenez do seu físico pulsa a vibração de uma inteligência vivaz e reside a amplitude de uma cultura esmerada. Debalde a modéstia que o envolve busca velar essas riquezas do seu espírito, porque estas, através da simplicidade dos seus hábitos, transparecem aos olhos de todos.

Participando no Supremo Tribunal da $2^{a}$ Turma, a que eu em determinado período presidi, foi-me dado ouvir os pronunciamentos que ele emitia, cinzelados em forma translúcida e moldados na mais escorreita doutrina jurídica. A par disso, a atividade febril com que ele se vinculava a um labor incansável possibilitava-lhe estar sempre em dia com o serviço forense.

No convívio com os colegas, ele sempre lhes dispensou um tratamento cortez e delicado, jamais se lhe notando, em relação a eles, um simples gesto de antipatia ou desagrado, porque, em verdade, isso não condiria com a nobreza dos seus sentimentos." 12

Nesse sentido, também, o Ministro Soares Muñoz quando, em nome da Corte, proferiu o discurso em homenagem ao Ministro Thompson Flores, por ocasião de sua aposentadoria, verbis:

"OMinistro Thompson Flores exerceu todos os cargos administrativos que a alta magistratura do País pode proporcionar. Integrou as três comissões regimentais, foi Vice-Presidente e Presidente do Tribunal Superior Eleitoral e, por igual, Vice-Presidente e Presidente do Supremo Tribunal Federal. No desempenho dessas funções, que impõem deveres complexos e difíceis e as responsabilidades mais sérias e excelsas, sempre se houve com invulgar êxito. Recebeu todas as dignidades a que um magistrado pode aspirar e soube realçá-las, 
inclusive, com a sua dignidade pessoal $\mathrm{e}$ funcional. Tudo fez em prol do Poder Judiciário, para que fosse distribuída a melhor justiça, aquela que ele idealizava:

"Justiça que brote de Juízes independentes, sem falsos ou mal compreendidos exageros. Justiça austera, impoluta, incorruptível, como se faz mister o seja, e para cujos imperativos prosseguiremos indormidos e intransigentes. Justiça humana, como merece distribuída às criaturas, feita à imagem de Deus. Justiça que jamais se aparte dos fins sociais e das exigências do bem comum, sem cujo conteúdo não teria nenhum sentido. Justiça que se aproxime, sem excessos ou enganosas formas, do próprio Povo, para o qual é ditada e do qual deve estar sempre ao alcance: simples, real, despida de tudo que a possa tornar dificultosa, a fim de que a compreenda melhor, sinta-a com mais fervor, e possa, assim, nela crer, para amá-la, prestigiála e defendê-la, se preciso for, convencido de que ela é o seu baluarte democrático e a sua mais sólida garantia. E, sobretudo, Justiça pontual, como a queria Rui, porque tarda não mereceria o nobre título. E como dizia, reclamando, "Para que paire mais alto que a coroa dos reis e seja tão pura como a coroa dos santos".

Só assim nos tornaremos dignos do respeito e da confiança da
Nação, ao lado dos demais Poderes da República".

Mas o alto conceito do Ministro Thompson Flores não deflui, unicamente, de sua capacidade de trabalho e do seu amor à justiça, dos seus dotes de inteligência e cultura, da seriedade, isenção e pontualidade com que exerceu a magistratura; outras virtudes e qualidades ornamlhe também a personalidade, singularizando-o como ser humano admirável. Suas intervenções, no Plenário, na Turma ou em sessões de conselho, sempre se fizeram no momento adequado, com elegância de saber discutir, sem contundência, policiando-se para falar apenas o necessário. $\mathrm{O}$ cavalheirismo, a cortesia, a suavidade de maneiras, a modéstia cativante, a tolerância, a afabilidade tornaram-no alvo da amizade dos colegas, da estima dos advogados e do afeto filial dos funcionários da Casa.

Em pleno vigor físico e intelectual, com o serviço que lhe fora distribuído rigorosamente em dia, foi surpreendido pela idadelimite e em consequência aposentado compulsoriamente. Cumpriuse, inexoravelmente, o preceito constitucional. O Supremo Tribunal Federal perdeu um grande Juiz. O Ministro Thompson Flores, no entanto, continuará presente nos fastos da Justiça Brasileira, não só como um grande Juiz, mas como um Juiz exemplar."13

13 In: Diário da Justiça da União, edição de 27.03.1981, p. 2.531. 
Preocupado com o crescente peso das atividades do Supremo Tribunal Federal, o Ministro Thompson Flores elaborou várias propostas no sentido de evitar que o congestionamento dos trabalhos do Tribunal se tornasse invencível.

Foi de sua iniciativa a proposta que deu origem ao $\S 1^{\circ}$ do art. 119 da Constituição Federal de 1967, na redação da Emenda $n^{\circ} 1 / 69$, que atribuiu ao Supremo Tribunal Federal a competência para indicar, em seu regimento interno, as causas a que se refere o item III, alíneas "a" e "d", do mencionado artigo.

Comfundamentonessedispositivo da Constituição foi que o Supremo Tribunal Federal instituiu, em 1975, a relevância da questão federal como condição de admissibilidade do recurso extraordinário.

Nesse sentido, também, a seção concernente ao recurso extraordinário do CPC de 1973 partiu de proposta por ele elaborada.

Eleito pelo Supremo Tribunal Federal, presidiu a Comissão que elaborou o célebre Diagnóstico do Poder Judiciário, composto de 94 volumes anexos, tido até hoje como o estudo mais completo acerca dos males que afligem a Justiça Brasileira.

Esse trabalho notável, publicado na íntegra pela Revista Forense, v. 251 , pp. 7 e seguintes, subsidiou o legislador constituinte quando da edição da Emenda Constitucional $n^{\circ}$
7/77 que estabeleceu a Reforma do Judiciário.

Para o devido registro da história do Poder Judiciário, convém recordar a introdução desse importante documento, verbis:

"A honrosa visita de cortesia do Sr. Presidente da República ao Supremo Tribunal Federal, no dia 16 de abril de 1974, revestiu-se do caráter de profícuo encontro entre o Chefe do Poder Executivo e a mais alta hierarquia do Poder Judiciário, para declarações concordantes dos dois Poderes, da maior relevância para a justiça e, portanto, para a Nação. Afirmaram-se naquele diálogo: a necessidade e oportunidade de reforma do Poder Judiciário; a disposição de fazer o Governo do Presidente ERNESTO GEISEL o que puder para o aprimoramento dos serviços da justiça; a conveniência de prévia fixação, pelo próprio Poder Judiciário, do diagnóstico da justiça, mediante o levantamento imediato dos dados e subsídios necessários.

1. Em decorrência do interesse do Governo, na reforma, o senhor Ministro ARMANDO FALCÃO entrou em entendimento com o eminente Ministro ELOY DA ROCHA, presidente do Supremo Tribunal Federal. Ficou assentado, nessa ocasião, que, inicialmente, o Poder Judiciário procederia aos imprescindíveis estudos, em cada área de atividade jurisdicional, na medida em que aos Tribunais parecesse recomendável a ação reformadora. 
2. Para desempenhar-se do encargo, foram solicitadas às justiças especiais e à justiça comum estatísticas, informações e sugestões, bem como a contribuição de universidades, de associações de classe, de magistrados, advogados e outros juristas.

Os dados e as opiniões obtidos constam de noventa e quatro volumes anexos. Foram apresentados relatórios parciais, relativos à Justiça Federal, à Justiça Militar, à justiça do Trabalho, à justiça Eleitoral, às Justiças dos Estados e à Justiça do Distrito Federal, nos quais se encontram, a par de algumas observações de ordem geral, problemas específicos das respectivas áreas de exercício jurisdicional.

Esses relatórios parciais se consideram, pois, incorporados ao presente, que constitui uma visão resumida dos problemas mais graves do Poder Judiciário.

A pesquisa feita indica, sem que se precise descer a pormenores, que a reforma da justiça, ampla e global, sem prejuízo do sistema peculiar à nossa formação histórica, compreenderá medidas sobre recrutamento de juízes a sua preparação profissional, a estrutura e a competência dos órgãos judiciários, o processo civil e penal (e suscitará, mesmo, modificação de regras de direito material), problemas de administração, meios materiais e pessoais de execução dos serviços auxiliares e administrativos, com aproveitamento de recursos da tecnologia. Avultarão, na reforma, ainda, problemas pessoais dos juízes, seus direitos, garantias, vantagens, deveres e responsabilidades. E visará a assegurar o devido prestígio à instituição judiciária, que, no regime da Constituição, se reconhece como um dos três Poderes, independentes e harmônicos.

3. A extensão da pesquisa realizada corresponde à ideia de que a reforma do Poder Judiciário deve ser encarada em profundidade, sem se limitar a meros retoques de textos legais ou de estruturas. Querse que o Poder Judiciário se torne apto a acompanhar as exigências do desenvolvimento do país e que seja instrumento eficiente de garantia da ordem jurídica. Quer-se que se eliminem delongas no exercício da atividade judiciária. Quer-se que as decisões do Poder Judiciário encerrem critérios exatos de justiça. Quer-se que a atividade punitiva se exerça com observância das garantias da defesa, com o respeito à pessoa do acusado e com a aplicação de sanções adequadas. Quer-se que à independência dos magistrados corresponda o exato cumprimento dos deveres do cargo. Quer-se que os jurisdicionados encontrem, no Poder Judiciário, a segura è rápida proteção a restauração de seus direitos, seja qual for a pessoa ou autoridade que os ameace ou ofenda.

4. Reforma de tal amplitude não se fará sem grandes esforços. Há dificuldades técnicas a resolver. Serão necessários meios para corresponder a encargos financeiros indispensáveis. $\mathrm{E}$ há interesses que hão de ser contrariados ou desatendidos. 
Impor-se-á alteração de textos constitucionais e legais e será mister disciplina. unitária de direitos e deveres de magistrados.

É certo que a reforma poderá implantar-se por partes. Mas determinadas medidas, que dizem com a essência dela, ou serão preferencialmente executadas, ou não haverá, na realidade, reforma eficaz." 14

No dia 14 de fevereiro de 1977 , o Ministro Carlos Thompson Flores tomou posse como Presidente do Supremo Tribunal Federal para o biênio 1977/1979.

Em seu discurso assumiu o compromisso de dedicar-se integralmente em prol do Poder Judiciário, visando ao seu aperfeiçoamento, para que fosse distribuída a melhor Justiça, aquela que ele tanto idealizava, verbis:

"Grave, penoso, por vezes antipático, a cada passo incompreendido, exigindo sempre equilíbrio $e$ coragem, a missão do juiz, inobstante, impende ser cumprida para que a lei, como expressão do Direito, tenha execução, e a Justiça jamais falte entre nós.

Justiça que brote de juízes independentes, sem falsos ou mal compreendidos exageros, como sempre o foram os juízes do Rio Grande, reconhecidos urbe et orbe, sem cujo atributo nem é possível conceber o exercício funcional como ele se impõe.

Justiça austera, impoluta, incorruptível, como se faz mister o seja e para cujos imperativos prosseguiremos indórmitos e intransigentes.

Justiça humana como merece distribuída às criaturas feitas à imagem de Deus.

Justiça que jamais se aparte dos fins sociais e das exigências do bem comum, sem cuja presença nem seria compreendida.

Justiça que se aproxime, sem excessos ou enganosas fórmulas, do próprio povo para a qual é ditada e do qual deve estar sempre ao alcance; simples, real, despida de tudo que a possa tornar dificultosa, a fim de que a compreenda melhor, sinta-a com fervor, e possa, assim, nela crer para amá-la, prestigiá-la, e defendê-la se preciso for, convencido que ela é seu baluarte democrático e a sua mais sólida garantia.

Justiça da qual se não permita desconfiar um só segundo, porque como assinalava Balzac: "Desconfiar da Magistratura é um começo de dissolução social".

E sobretudo Justiça pontual, como a queria Rui, porque tarda não

14 In: Reforma do Poder Judiciário - Diagnóstico, Supremo Tribunal Federal, 1975, p. $11 / 5$. 
mereceria o nobre título. E como dizia, reclamando: "Para que paire mais alto que a coroa dos reis e seja tão pura como a coroa dos santos".

Só assim nos tornaremos dignos do respeito e da confiança da Nação, ao lado dos demais Poderes da República." ${ }^{15}$

Ajusta-se com propriedade ao seu pensamento aquela passagem de Michel Debré, Ministro da Justiça do Presidente De Gaulle, a respeito da sua preocupação com o aperfeiçoamento e modernização do Judiciário:

"Je suis de ces républicains qui rêvent d'une justice habile et prompte, sévère et humaine, condamnant ceux qui méritent de l'être, protégeant l'innocence, statuant avec équité en tous domaines. Il me paraît que la valeur de la justice et le respect dont ses décisions sont entourées attestent du degré de civilisation qu'un peuple a atteint." 16

A sua presidência foi marcada de realizações.

No plano administrativo, foram tomadas as seguintes medidas: promoveu-se ampla reforma da Secretaria da Corte, medida há muito reclamada pelos advogados; a publicação interna, para uso exclusivo dos Ministros e assessores, do boletim do Supremo Tribunal Federal, destinado ao acompanhamento das decisões do Plenário e das Turmas logo após proferidas, experiência instituída pelo Ministro Carlos Thompson Flores quando presidente do Tribunal de Justiça do Rio Grande do Sul; o retorno do Plenário ao edifíciosede após a conclusão das obras na gestão do Ministro Djaci Falcão; a inauguração, em dezembro de 1977, da Galeria dos retratos dos Presidentes da Corte, desde a instalação em 1829; a instalação do Museu do Supremo Tribunal Federal, abarcando peças e documentos históricos vinculados à Corte, inclusive com a remoção do mobiliário da antiga sala de sessões do Supremo Tribunal Federal no Rio de Janeiro, que foi trazido para Brasília, completamente restaurado e instalado no edifício-sede; a transferência da biblioteca para o $3^{\circ}$ andar do edifício-sede; a classificação e catalogação do acervo, bem como a sua ampliação mediante a aquisição de novas obras; a atualização da Revista Trimestral de Jurisprudência,

15 In: Revista Forense, v. 257, p. 424-5.

16 In: Debré, Michel. Trois Républiques pour une France: Mémoires, Albin Michel, 1988, t. II, p. 333. 
inclusive com a publicação de acórdãos da década de 1950 e início dos anos seguintes; início da construção do bloco de apartamentos destinado exclusivamente à residência dos Ministros do Supremo Tribunal Federal; criação do serviço de auditoria da Corte com a aprovação da Lei $n^{\circ}$ 6.474/77; foram acelerados os entendimentos com o Poder Executivo para a obtenção de área contígua ao Tribunal destinada à construção do Anexo II; a regulamentação das normas do cerimonial das sessões solenes do Tribunal, através da Portaria $n^{\circ} 148 / 78$; a celebração de convênio com o Senado, possibilitando acesso aos bancos de dados já existentes e visando à inclusão da jurisprudência da Corte no PRODASEN, constituindo-se no embrião da informatização dos serviços do Tribunal.

Dentro da filosofia de incentivo aos funcionários situados em faixa salarial mais reduzida, adotaram-se as seguintes providências, verbis:

a) "ajuda-alimentação", constante no pagamento de $80 \%$ do valor da refeição, fornecida por restaurante existente nas dependências do Supremo Tribunal Federal;

b) construção e instalação do gabinete odontológico;

c) implantação do transporte para funcionários residentes nas cidades-satélites; d) contratação dos serviços de um médico ginecologista para atendimentos das servidoras;

e) assinatura de convênio com a Central de Medicamentos para fornecimento gratuito de remédios.

No plano institucional, dois eventos se projetaram na Presidência Thompson Flores: a implantação da reforma do judiciário, por meio da Emenda Constitucional $n^{\circ} 7 / 77$, que acrescentou novas e importantes atribuições para o Supremo Tribunal Federal, destacando-se o Conselho Nacional da Magistratura; e a comemoração dos 150 anos do Supremo Tribunal Federal, com ampla divulgação por todo o país da efeméride.

A propósito, impõe-se destacar a introdução feita pelo Presidente Thompson Flores na obra "O Legislativo e a Organização do Supremo Tribunal no Brasil", editada pela Câmara dos Deputados, onde são assinalados aspectos marcantes da história do Supremo Tribunal Federal.

Disse o Ministro Thompson Flores, verbis:

"O movimento libertador que culminou, em 1822, com a Independência, tornou imperiosa a necessidade de criar e pôr em funcionamento os órgãos que iriam compor a estrutura do novo Estado, 
jovem Nação, liberta da subordinação à Metrópole.

Por esse motivo a década transformou-se em palco de eventos de grande significação, consubstanciadores das providências adotadas para consolidar a nova situação do País.

As ideias constitucionalistas e liberais que agitavam as Cortes europeias e, em particular, a de Portugal, exerceram profunda influência sobre o processo de constitucionalização do Brasil que, segundo registram os historiadores, ter-se-ia desenvolvido simultaneamente com o desejo de promover a libertação completa e definitiva da terra brasileira.

Fruto desse processo é o documento constitucional do Império, outorgado a 25 de março de 1824 , que acolheu em seu bojo, dentre outros, o princípio preconizado por LOCKE e desenvolvido por MONTESQUIEU, da repartição dos poderes do Estado, à tradicional divisão tripartite sobrepôs, contudo, o elemento de controle e equilíbrio a ser representado pelo Poder Moderador, exercido pessoalmente pelo Imperador, visando preservar, inegavelmente, a essência do autoritarismo monárquico.

Nesse contexto iniciou o Poder Legislativo suas atividades em 1826, através da Assembleia Geral, dividida em Câmara dos Deputados e Senado, este vitalício e aquela temporária, passando a elaborar as leis básicas a garantir a liberdade e soberania do País.

Atendendo aos reclamos da juventude brasileira, obrigada a buscar nos estabelecimentos de ensino europeus sua formação superior, houve por bem o órgão legiferante, recéminstalado, criar "dois cursos de ciências jurídicas e sociais, um na cidade de São Paulo e outro na de Olinda", por lei de 11 de agosto de 1827, introduzindo, entre nós, o estudo universitário.

No que concerne ao Poder Judiciário ou "Poder Judicial", como foi então chamado e que era único para todo o Império, não havendo magistraturas provinciais, previa a nossa primeira Constituição, no art. 163, a criação de um órgão de cúpula, a denominarse Supremo Tribunal de Justiça, com atribuições peculiares e distintas das que foram conferidas aos demais integrantes do organismo.

Assinale-se que, quando da transmigração da Família Real portuguesa para o Brasil, já havia o Príncipe Regente transformado a Relação do Rio de Janeiro em Casa da Suplicação do Brasil, "considerada como Superior Tribunal de Justiça, para se findarem ali todos os feitos em última instância, por maior que seja o seu valor, sem que das últimas sentenças proferidas em qualquer das Mesas da sobredita Casa se possa interpor outro recurso que não seja o das revistas", mediante o Alvará de 10 de maio de 1808 , à semelhança de órgão existente em Lisboa.

Essa Corte embora possa ser o precedente histórico do Supremo Tribunal de Justiça - Supremo Tribunal Federal com o advento da República - com ele não se confunde, em face, sobretudo, da nítida diferenciação que entre os dois 
produziu a libertação política do País e do surgimento, posterior, de uma legislação genuinamente brasileira, em substituição às Ordenações portuguesas, até então vigentes e aplicáveis aos brasileiros.

É de indagar-se, pois, quais teriam sido as causas que levaram o legislador constituinte do novo Estado a imaginar, no ápice do sistema judiciário, um tribunal ímpar, superposto aos demais componentes do Poder e, ainda, distinto de seu predecessor.

PIMENTA BUENO em seus comentários à Constituição do Império, abordou com maestria a questão, enfatizando duas ordens de fatores que teriam contribuído predominantemente.

A primeira, afirma $o$ autor, relacionava-se à circunstância de que, esgotadas as duas instâncias ordinárias nas quais os fatos e o direito eram exaustivamente examinados, impunha-se a existência de um órgão maior, que viesse a apreciar a questão suscitada, já agora não mais apenas em razão dos direitos ou aspirações individuais, mas "em relação ao interesse da ordem pública, do império da Lei, questão de alta importância, que cumpria resolver com inteiro acerto".

Por outro lado, destacava, fazendo clara referência ao problema da diversidade jurisprudencial,

há uma multidão de tribunais, cada um dos quais tem sua inteligência e vontade distinta, e que ainda mesmo sem intenção de abuso, pode seguir doutrina diversa, tanto mais porque a aplicação das leis nem sempre se faz sem dúvida $\mathrm{e}$ dificuldades, mesmo por causa da concisão de seus preceitos; e uma tal divergência romperia a unidade da lei, que deve ser igual e a mesma para todos.

Era essencial, portanto, criar uma entidade, uma instituição mista, de caráter político-judiciário que, não sendo uma terceira instância, viesse a cumprir o alto encargo de exercer uma

elevada vigilância, uma poderosa inspeção e autoridade, que defendesse a lei em tese, que fizesse respeitar o seu império, o seu preceito abstrato, indefinido, sem se envolver na questão privada, ou interesse das partes, embora pudesse aproveitar ou não a elas, por via de consequência.

Para cobrir todo esse amplo espectro de atribuições, inclinaram-se os elaboradores da Carta Imperial pelo Supremo Tribunal de Justiça, corte específica, de composição que o próprio texto constitucional fixava com missão especial, "mais política do que judicial", no dizer, ainda, de PIMENTA BUENO.

A previsão constitucional, por si só, não tinha o condão de dar existência real ao órgão. Coube à Assembleia Geral dar vida ao disposto no art. 163 do documento político do Império; por suas duas Casas tramitou o projeto apresentado por BERNARDO PEREIRA DE VASCONCELOS, na sessão da Câmara de 7 de agosto de 1826, transformado na Lei de 18 de setembro de 1828 , que criou e 
declarou as atribuições do Supremo Tribunal de Justiça.

Seus primeiros juízes, bem como seu Presidente, o Conselheiro JOSÉ ALBANO FRAGOSO, foram nomeados por ato do Imperador, de 19 de outubro de 1828 , e o decreto de 2 de janeiro de 1829 determinou que o Tribunal se instalasse a 9 daquele mesmo mês, dando início às atividades que tiveram curso, ininterruptamente, até a República.

A Carta Política de 1891 representou a síntese dos ideais republicanodemocráticos que conseguiram romper, de forma definitiva, com a tradição monárquica, até então imperante no País.

Tratou a Constituição de nossa Corte Suprema no art. 56, dispondo sobre sua composição e forma de nomeação de seu membros; adotou, ainda, a denominação Supremo Tribunal Federal, mais consentânea com a forma federativa que o Brasil, então, elegera.

Às antigas províncias, transformadas em Estados, concedeu-se autonomia legislativa; cada um deles passou a reger-se pela Constituição e leis que adotasse, respeitados os princípios constitucionais da União (art. 63); estabeleceram-se as justiças estaduais, com competência submetida aos limites fixados nos arts. 61 e 62 .

Inobstante tais inovações, as leis oriundas do Poder Legislativo federal deveriam ser observadas em todo o território nacional, fazendo com que se ampliasse, não apenas em volume de serviço, como em importância, a alta missão já antes deferida ao Supremo Tribunal Federal, de manter a uniformidade na interpretação do Direito.

Novo e relevantíssimo encargo foi conferido ao Poder Judiciário da República e, em particular, ao órgão de cúpula do sistema como seu portavoz derradeiro: o do controle da constitucionalidade de leis e atos do poder público, atribuído pela Carta Imperial ao Poder Legislativo (art. 15, IX, da Constituição de 1824).

Quanto a essa significativa modificação, assinalava JOÃO BARBALHO, em seus comentários à Constituição de 1891, que "nem fora necessário texto formal e explícito, atribuindo à magistratura o poder, ou antes o dever [...] de deixar de aplicar leis inconstitucionais", eis que estariam ambos ("poder" e "dever", implícitos na própria ação de julgar, na medida em que não poderiam ser exercidos com esquecimento ou preterição da Constituição, "fonte da autoridade judicial e lei suprema, não para os cidadãos somente, mas também para os próprios poderes públicos".

A Constituição de 16 de julho de 1934 modificou, no art. 73, a denominação do Tribunal para "Corte Suprema", desejando emprestar maior fidelidade ao modelo norteamericano que servira de inspiração ao constituinte de 1891. A alteração teve vida efêmera; pois, em 1937, a chamada Carta do Estado Novo preferiu utilizar, no art. 90, o antigo título "Supremo Tribunal Federal", consagrado, definitivamente, nos documentos básicos que se seguiram. 
PIMENTA BUENO, na obra antes referida ao finalizar as considerações desenvolvidas acerca do órgão previsto na Carta de 1824, afirmava profeticamente:

Tal é a natureza desta sublime instituição, ainda tão desconhecida e tão pouco considerada em nosso jovem País; ela porém está plantada no terreno constitucional, e a Providência há-de fecundá-la; háde ser entre nós o que é em outros Estados, aos quais tem prestado úteis e gloriosos serviços .

Se, à época, já causava espécie o desconhecimento que cercava a valiosa destinação e a incomparável significação da Corte, a situação não se modificou, substancialmente, ao longo desses 150 anos.

O fato não deve ser debitado, apenas, a um possível desinteresse ou descaso dos juristas e historiadores pátrios, tendo como consequência a escassa literatura sobre o órgão máximo da Justiça brasileira; grande parcela cabe, também, à própria Corte, em razão das características que pautaram, sempre, a atividade de seus ministros, avessos a qualquer tipo de publicidade.

Há que admitir a existência de preciosas lições, frutos da cultura e do trabalho laborioso de insignes juízes de nossa Corte maior, que jazem esquecidas em longínquas páginas de acórdãos, furtados ao conhecimento de advogados, estudantes e estudiosos do Direito por falta de uma divulgação ampla e adequada, com lamentável perda para a formação jurídica nacional.
Quanto aos bons augúrios formulados ao ensejo de sua criação, pode, hoje, o Supremo Tribunal Federal voltarse para seu passado, para o século e meio que o separa de seu nascimento, com a consciência tranquilizada não apenas pela sensação do dever cumprido; tem, antes, a certeza da missão diligenciada com profundo amor e dedicação à causa da Justiça, aos quais se aliaram, em todas as épocas, o brilho da inteligência e do saber jurídico daqueles que ocuparam postos em seu plenário.

Merece ser recordada a oração de RUI BARBOSA, proferida perante a Corte, em 23 de abril de 1892:

Minha impressão, neste momento, é quase superior às minhas forças, é a maior, com que jamais me aproximei da tribuna, a mais profunda com que a grandeza de um dever público já me penetrou a consciência, assustada da fraqueza do seu órgão. Comoções não têm faltado à minha carreira acidentada, nem mesmo as que se ligam ao risco das tempestades revolucionárias. Mas nunca o sentimento da minha insuficiência pessoal ante as responsabilidades de uma ocasião extraordinária, nunca o meu instinto da pátria, sob a apreensão das contingências do seu futuro, momentaneamente associado aqui às ansiedades de uma grande expectativa, me afogaram o espírito em impressões transbordantes, como as que enchem a atmosfera deste recinto, povoado de temores sagrados e esperanças sublimes.

Subjugado pela vocação desta causa incomparável, custa-me, 
entretanto, a dominar o respeito, quase supersticioso, com que me acerco deste Tribunal, o oráculo da nova Constituição, a encarnação viva das instituições federais. Sob a influência deste encontro, ante esta imagem do antigo areópago transfigurada pela distância dos tempos, consagrada pela América no Capitólio da sua democracia, ressurge-me, evocada pela imaginação, uma das maiores cenas da grande arte clássica, da idade misteriosa em que os imortais se misturavam com os homens. Atenas, a olímpica, desenhada em luz na obscuridade esquiliana, assentando, na rocha da colina de Arés, sobranceira ao horizonte helênico, para o regime da lei nova, que devia substituir a contínua alternativa das reações trágicas, o rito das deusas estéreis da vingança, pelo culto da justiça humanizada, essa magistratura da consciência pública, soberana mediadora entre as paixões, que destronizou as Eumênides atrozes.

O sopro, a que a República vos evocou, a fórmula da vossa missão, repercute a tradição grega, divinamente prolongada através da nossa experiência política: "Eu instituo esse Tribunal venerando, severo, incorruptível, guarda vigilante desta terra através do sono de todos, e o anuncio aos cidadãos, para que assim seja de hoje pelo futuro adiante."

Contém o presente volume a tramitação completa, nas duas Casas que compunham a Assembleia Geral do Império do Brasil, do projeto que originou a Lei de 18 de setembro de 1828 , que criou e declarou as atribuições do Supremo Tribunal de Justiça.

A Câmara dos Deputados, ao promover a publicação dos trabalhos legišlativos que resultaram na referida lei, presta à Corte a mais expressiva das homenagens, que sensibiliza tanto sua atual composição como, e principalmente, toda a cultura jurídica do País.

Deseja esta Presidência deixar consignados seus sinceros agradecimentos pelo nobre gesto, que amplia e fortalece os tradicionais laços de harmonia e colaboração existentes entre os Poderes Legislativo e Judiciário, manifesta, outrossim, o seu reconhecimento pela deferência de seu nobre Presidente, Deputado MARCO MACIEL, pelo convite para fazer esta introdução.

Brasília, 18 de julho de 1978.

Ministro

CARLOS THOMPSON FLORES

Presidente do Supremo

Tribunal Federal"17

17 In: O Legislativo e a Organização do Supremo Tribunal no Brasil, editado pelo Centro de Documentação e Informação da Câmara dos Deputados, Brasília, 1978, p. XIX-XXV. 
$\mathrm{Na}$ sessão solene realizada de contas de sua administração, em 18 de setembro de 1978, em comemoração do sesquicentenário do Supremo Tribunal Federal, compareceu o Presidente da República, acompanhado de todo o seu ministério, fato então inédito na história do Tribunal.

Nessa ocasião, em sessão solene por ele presidida, recebeu das mãos do Presidente da República, Ernesto Geisel, a mais alta condecoração da Nação, a Grã-Cruz da Ordem Nacional do Mérito.

$\mathrm{Na}$ oportunidade, assim se manifestou o Presidente da República:

"Na oportunidade em que se comemoram 150 anos da existência do Supremo Tribunal Federal, o Conselho da Ordem Nacional do Mérito propôs conferir a V. Exa., e eu acedi, o grau de Grã-Cruz da referida Ordem.

Este ato é uma homenagem do Poder Executivo ao Poder Judiciário (...) Mas é, principalmente, o reconhecimento dos elevados méritos de V. Exa., Sr. Ministro-Presidente, do trabalho que tem desenvolvido, ao longo de sua vida, como cidadão e como magistrado, em benefício da Nação brasileira." 18

Ao concluir o relatório da sua Presidência, em verdadeira prestação consignou, em palavras carregadas de emoção, verbis:

"Ao concluir este Relatório manifesto a convicção de que procurei corresponder, tanto quanto me foi possível e nos limites das minhas forças, ao mandato que os Senhores Ministros me confiaram. Após 45 anos de existência dedicada à magistratura, tenho a sensação do dever cumprido.

Para isto muito contribuíram, no último biênio, a colaboração e o empenho dos Senhores Ministros, propiciando os resultados atingidos, que exteriorizam a elevada carga de trabalho recebida pela Corte, sem solução de continuidade. Inobstante os esforços desenvolvidos, a massa de feitos que chega, anualmente, não se reduz. Confrontando os elementos concernentes aos anos de 1977 e 1978, verifica-se que ocorreu, no global, um acréscimo de 1.074 feitos, destacando-se as Arguições de Relevância, que ascenderam, de 1.172 a 1.719 , com o aumento percentual de $46,67 \%$.

De forma generalizada isto ocorre em relação a todos os Órgãos do Poder Judiciário, dos Juizados de $1^{\text {a }}$ instância aos Tribunais Superiores, revelando os sacrifícios a que estão expostos os magistrados, numa vida que exige vocação, desprendimento, renúncia e estudo permanente.

18 In: Diário da Justiça da União, edição de 19.10.1978, p. 8.164. 
Esta realidade deve sensibilizar os demais Poderes da República, para que, através de modificações adequadas na legislação, possam criar condições hábeis para o pleno reconhecimento das nobres funções dos Juízes, para a ampliação dos quadros, com o correspondente apoio administrativo e, ainda, com a adequação das normas processuais, possibilitando a realização de uma Justiça mais rápida e eficaz.

Quando terminei o Relatório precedente, exteriorizei a esperança de que 1978 pudesse também ser assinalado pela aprovação da Lei Orgânica da Magistratura Nacional, que correspondesse aos anseios dos Juízes. Isto não se tornou possível, mas renovo a crença de que os membros do Poder Legislativo, onde se encontra atualmente $o$ projeto, imbuídos dos propósitos de bem servir ao Brasil, aprovarão, na próxima legislatura, um diploma que corporifique as expectativas da Justiça Nacional.

Outrossim, a não aprovação da citada lei obstou o prosseguimento dos trabalhos da Comissão de Regimento, a qual considerou indispensável dita aprovação.

Havia a Secretaria apresentado, em junho último, alentado estudo sobre a reforma, nele incluindo as alterações que sobre ele incidiram a Emenda Constitucional $\mathrm{n}^{\circ} 7$, o vigente Código de Processo Civil e as novas Emendas Regimentais.

De outra parte, a revisão das Súmulas afeta à Comissão de Jurisprudência, à qual foram enviados os estudos procedidos pela Assessoria, não logrou findar seus trabalhos.

Confio que as relevantes tarefas, de tão significativo préstimo a todos que versam com a aplicação do direito, terão prosseguimento, embora reconheça que será mais um encargo a acrescer às já penosas atribuições dos Senhores Ministros.

Quero consignar que as comemorações dos 150 anos deste Tribunal, com a divulgação correspondente, tornaram-no menos desconhecido, possibilitando que milhões de brasileiros, alcançados pela imprensa escrita, falada e televisionada, tomassem ciência da efeméride. Que esta divulgação não represente apenas um episódio, tornando-se uma constante, é o meu desejo, para que esta Corte, a exemplo do que ocorre em outros países, possa ser respeitada, admirada e amada, como o supremo baluarte dos direitos de cada cidadão. ${ }^{19}$

Aos 26 de janeiro de 1981, no dia mesmo em que completava setenta anos, aposentou-se, após meio século dedicado exclusivamente à magistratura.

19 In: Relatório da Presidência Thompson Flores, Supremo Tribunal Federal, 1977, p. $26 / 7$. 
$\mathrm{Na}$ sessão plenária realizada a 11 de março de 1981, por motivo de sua aposentadoria, assinalou em seu discurso o Procurador-Geral da República, Dr. Firmino Ferreira Paz, verbis:

"Esta homenagem, que o Supremo Tribunal Federal ora presta a Vossa Excelência, Senhor Ministro Carlos Thompson Flores, e a que se associa, por meu intermédio, cordialmente, o Ministério Público Federal, é o testemunho eloquente do grande apreço, da profunda admiração e do puro respeito, que todos votamos à notável personalidade de Vossa Excelência, ao juiz exemplar, ao jurista de escol, ao amigo afetuoso, ao patriota sem jaça, e ao brasileiro perante o qual, neste momento, se curva, reverencialmente agradecida, a mais alta expressão da Justiça brasileira, que é o Supremo Tribunal Federal.

Esta homenagem é, a todas as luzes, julgamento público e supremo daquele que, por quase meio século, dedicou todos os momentos de sua vida honrada à distribuição de Justiça a quantos lha pediam. Julgou. Agora, está sendo julgado e proclamado um dos mais eminentes, honrados e cultos juízes do Brasil.

Para que alguém, por tantos e tantos anos, sem o mínimo desvio de propósitos, ponha, a serviço de uma causa, força e dedicação constantes, é preciso ideal e viver dele. E o mais nobre, mais sublime, o mais excelso, o mais divino, não há que o de ser justo. Desse ideal, senhores, viveu e vive o eminente Ministro
Thompson Flores.

Julgar, servindo ao Poder Judiciário, é forma de realizar o Direito, prevenindo ou extinguindo conflitos sociais objetos de demandas forenses. É forma de promover a adaptação dos homens entre si, em convivência social.

Não fossem, entre os homens individualmente considerados, ou entre grupos sociais, os conflitos que a vida, em sociedade, provoca, e, mais do que isso, a prevenção ou a extinção desses conflitos, não havia, dentre os processos sociais de adaptação, o Direito.

Os conflitos humanos, sejam quais lhes forem os motivos determinantes, são factos. Uns são preveníveis; outros, extintíveis. A prevenção e a extinção, de sua vez, realizam-se em factos. Dessa sorte, facto previne ou extingue facto, é dizer, previne ou extingue conflito social. Opera-se, outrossim, em consequência, a adaptação social, fim último do Direito.

$\mathrm{O}$ que se sabe e aprende, todos os dias, nos Juízos ou Tribunais, é que a função judicial visa a realizar a prevenção ou a extinção dos conflitos entre os homens, para alcançar a adaptação social.

Assim, pois, em última análise, o acto judicial de julgar é, também, conceptualmente, Direito.

Dessas razões, sucintamente expostas, podemos dizer que o eminente Ministro Thompson Flores, por quase meio século, julgando, e o fazendo com sabedoria e prudência, fora, neste País, por todos os caminhos 
da judicatura, ascencionalmente, admirável e brilhante realizador do Direito no Brasil. Ninguém, nesse mister, o terá superado em dedicação, em amor às letras jurídicas, em senso de responsabilidade, em coragem e em grandeza de atitudes.

Neste Colendo Supremo Tribunal Federal, último estágio da judicatura exercida pelo nosso homenageado, figuram-lhe, nos anais, os votos brilhantes proferidos pelo eminente Ministro Carlos Thompson Flores, a quem, incontestavelmente, devem as letras jurídicas nacionais grande $\mathrm{e}$ brilhante contribuição.

Receba, Excelentíssimo Senhor Ministro Thompson Flores, por último, do Ministério Público Federal e de mim próprio, nossas homenagens, em sinal de respeito profundo, sincera amizade $\mathrm{e}$ admiração incondicional, a par de nossos votos de muitas e muitas felicidades. ${ }^{20}$

Do primoroso discurso proferido pelo saudoso Ministro Soares Muñoz, que falou em nome do Tribunal, destaco a seguinte passagem, verbis:

"Mas o alto conceito do Ministro Thompson Flores não deflui, unicamente, de sua capacidade de trabalho e do seu amor à justiça, dos seus dotes de inteligência e cultura, da seriedade, isenção e pontualidade com que exerceu a magistratura; outras virtudes e qualidades ornamlhe também a personalidade, singularizando-o como ser humano admirável. Suas intervenções, no Plenário, na Turma ou em sessões de conselho, sempre se fizeram no momento adequado, com elegância de saber discutir, sem contundência, policiando-se para falar apenas o necessário. $\mathrm{O}$ cavalheirismo, a cortesia, a suavidade de maneiras, a modéstia cativante, a tolerância, a afabilidade tornaram-no alvo da amizade dos colegas, da estima dos advogados e do afeto filial dos funcionários da Casa.

Em pleno vigor físico e intelectual, com o serviço que the fora distribuído rigorosamente em dia, foi surpreendido pela idade-limite e em consequência aposentado compulsoriamente. Cumpriu-se, inexoravelmente, o preceito constitucional. $\mathrm{O}$ Supremo Tribunal Federal perdeu um grande Juiz. O Ministro Thompson Flores, no entanto, continuará presente nos fastos da Justiça Brasileira, não só como um grande Juiz, mas como um Juiz exemplar."21

Significativa homenagem foilhe prestada pelo editorial do Jornal do Brasil, edição de 29.08.1981, ao enfatizar a necessidade da retomada do processo da reforma do Poder Judiciário, assinalando, verbis:

20 In: Diário da Justiça da União, edição de 27.03.1981, p. 2.531/2.

21 In: Diário da Justiça da União, edição de 27.03.1981, p. 2.531. 
"Há indícios de que o Supremo Tribunal Federal deseja aproveitar a oportunidade de se encontrar na Chefia do Gabinete Civil da Presidência da República seu exPresidente, para recolocar, agora em termos próprios e, com todas as probabilidades de se fazer ouvir com a atenção devida, a questão da reforma do Judiciário. O Ministro Xavier de Albuquerque chegou a fazer referência pública e expressa à possibilidade de um novo trabalho nesse sentido, cuja realização, além de corresponder a necessidades concretas da sociedade brasileira, seria ou será um complemento indispensável ao projeto político do atual Governo.

É preciso voltar ao "diagnóstico", que se acha impregnado daquele ideal de Justiça expresso por um dos mais puros juízes - Thompson Flores em voto proferido no STF: "Justiça que se aproxime, sem excessos ou enganosas formas, do próprio povo, para o qual é ditada e do qual deve estar sempre ao alcance: simples, real, despida de tudo que a possa tornar dificultosa, a fim de que compreenda melhor, sinta-a com mais fervor e possa defendê-la, se preciso, convencido de que ela é o seu baluarte democrático; sua mais sólida garantia."

A aposentadoria não pôs termo à sua atividade em prol do direito e da justiça.

De março de 1981 a novembro de 1992 produziu inúmeros pareceres, muitos deles publicados nas revistas especializadas. $^{22}$

Questão constitucional interessante foi o mandado de segurança da "Mesa da Assembleia" do Rio Grande do Sul, em que restou examinada a validade da deliberação tomada pelo

22 Após a sua aposentadoria dedicou-se, como jurisconsulto, ao estudo do Direito, emitindo Pareceres em inúmeras questões forenses, sendo que vários desses trabalhos encontram-se publicados em repertórios jurídicos: "Eleição dos Membros da Mesa da Assembleia Legislativa - Interpretação do art. 31 da CF", In: Revista Forense, v. 303/128; "Responsabilidade Civil Contratual", In: Revista de Direito Civil, no 42/147; "ICM e Compra com Cartão de Crédito", In: Revista de Direito Tributário, no 34/86; "Desapropriação - Empresa de Ônibus", In: Revista de Direito Público, n 95/42; "Imunidade Tributária das Listas Telefônicas", In: O Estado de São Paulo, Edição de 01/11/87, p. 38; “Ação Popular - Pressupostos Processuais”, In: Revista de Processo, no 61/218; "Montepio da Família Militar - Relação Jurídica entre a Entidade e seus Sócios - Pensões por eles instituídas - Alterações de seu Valor-Validade", In: Revista Forense, v. 351/311-320; "Desapropriação - Homologação de Transação - Efeitos Processuais", In: Revista de Direito Processual Civil, n 14, pp. 839/846; "Doação Inoficiosa - Art. 1.176 do CC - Querela Inofficiosae Donationis - Requisitos", In: Revista da Faculdade de Direito da UFRGS, v. 19/299-306; "Concurso - Classificação - Direito Adquirido", 
legislativo daquele Estado quando da eleição da Presidência da Casa.

O caso foi de grande repercussão jurídica e política, tendo sido julgado em definitivo pelo Supremo Tribunal Federal em decisão plenária apertada, tomada pela maioria de um voto.

O parecer do Ministro Thompson Flores foi acolhido pela Corte, ao julgar o RE $\mathrm{n}^{\circ}$ 95.778-RS, publicado na RTJ 102/433.

Pela sua atualidade, impõese rememorar excertos do parecer, fundamentado na lição dos clássicos, inclusive Duguit, verbis:

\section{"1. Dispõe a Constituição Federal de 1969:}

"Art. 31. Salvo disposição constitucional em contrário as deliberações de cada Câmara serão tomadas por maioria de votos, presente a maioria de seus membros."

Igualmente, estatui a Constituição do Estado:

"Art. 13. Ressalvados os casos expressos nesta Constituição, as deliberações serão tomadas por maioria de votos, presente a maioria dos membros da Assembleia.

Parágrafo único. $\mathrm{O}$ voto será secreto nas eleições e nos casos previstos nesta Constituição."

Lê-se, por fim, no Regimento Interno da Assembleia Legislativa:

"Art. 15. A eleição dos membros da Mesa far-se-á, por votação secreta, observadas as seguintes normas:

a) presença da maioria absoluta dos Deputados;

b) emprego de cédulas impressas ou datilografadas;

c) colocação da cédula em sobre carta, na cabina indevassável, e da sobrecarta na urna, à vista do Plenário;

d) escrutínio dos votos e proclamação do resultado da eleição;

e) obtenção da maioria absoluta de votos em primeiro escrutínio;

f) realização de segundo escrutínio entre os dois candidatos mais votados, quando no primeiro nenhum deles houver alcançado a maioria absoluta;

In: Revista de Direito Administrativo, v.225, pp.417/425; "Honorários advocatícios. Contrato quota-litis. Ação de cobrança. Prescrição", In: Revista Forense, v.359/181190; "Tribunal de Justiça - Quinto Constitucional - Composição - Acesso dos Juízes Classistas do Tribunal de Alçada ao Tribunal de Justiça", In: Revista da Faculdade de Direito da UFRGS, v.21/39-48; "Ato Ilícito Contratual - Indenização - Correção Monetária - Súmula 562 do STF”, In: Revista de Doutrina da $4^{a}$ Região, publicada pela Escola do TRF/4 $4^{\mathrm{a}}$ Região - EMAGIS, Edição 05, de 08.03.05; e na Revista do TRF/4 Região, vol. 55/83-96. 
g) maioria simples no segundo escrutínio;

h) escolha do candidato mais idoso, em caso de empate.

$\S 10^{\circ}$ O Presidente convidará dois Deputados de Bancadas diversas para procederem à apuração.

$\S 2 .^{\circ}$ A posse dos eleitos será imediata à proclamação do resultado pelo Presidente da sessão."

2. Esses foram os dispositivos legais invocados pelas partes e com os quais operaram os julgadores, posto que, pela argumentação jurídica que deduziram, não se harmonizassem na conclusão.

É certo que, preliminarmente, rejeitaram, além de outras, destituídas de maior importância, a de não conhecimento do mandado, negando que se configurasse no caso questão interna corporis, exclusivamente política.

Perdeu ela, a esta altura do andamento do recurso extraordinário, qualquer interesse. E isto porque ao recurso dos vencidos interposto não foi o adesivo dos vencedores no mérito, mas perdedores da prejudicial em questão, e só ele, nos termos do art. 500 do C. Pr. Civ. que, segundo o ensinamento de BARBOSA MOREIRA, abriria ensejo ao reexame daquela prefacial (Comentários ao C. Pr. Civ. vol. $\mathrm{V}$, FORENSE 3. ${ }^{\mathrm{a}}$ ed., 1978, $\mathrm{n}^{\mathrm{o}} \mathrm{s}$ 168 e 176).

De qualquer sorte, porém, impende afirmar que, com inteiro acerto, se conduziu, nesse passo, o $\mathrm{v}$ acórdão ora recorrido.

Com ele está a melhor doutrina nacional e estrangeira, recolhida por CASTRO NUNES, a qual the permitiu assim concluir:

" $\mathrm{Na}$ verdade, os tribunais não se envolvem, não examinam, não podem sentenciar, nem apreciar, na fundamentação das suas decisões, as medidas de caráter legislativo ou executivo, políticas ou não, de caráter administrativo ou policial, sob aspecto outro que não seja o da legitimidade do ato, no seu assento constitucional ou legal. Mas, nessa esfera restrita, o poder dos tribunais não comporta, em regra, restrição fundada na natureza da medida" ("Teoria e Prática do Poder Judiciário", p. 607).

No mesmo sentido é a jurisprudência do eg. STF de todos os tempos, rememorada pelo eminente $\mathrm{e}$ saudoso Ministro LUIZ GALLOTTI, ao relatar o MS n. 1.959, julgado em 23.01.57, invocando decisões anteriores (EDGARD COSTA, "Os Grandes Julgamentos do STF", vol. III, 1964, ps. 204 e segs.; REVISTA FORENSE, 148, ps. 152 e segs.) Da ementa do julgado, destaco:

"Desde que se recorra ao Judiciário, alegando que um direito individual foi lesado por ato de outro Poder, cabe-lhe examinar se esse direito existe e se foi lesado.

Eximir-se com a escusa de tratar-se de ato político seria fugir ao dever que a Constituição lhe impõe, maxime após ter ela inscrito, entre as garantias fundamentais, como nenhuma outra o fizera, o princípio de que nem a lei poderá excluir da apreciação do Poder Judiciário qualquer lesão do direito individual." 
Dita orientação foi reiterada no RMS n. 11.140, MT, julgado em 10.06 .63 (RDA, vol. 74, ps. 267/71).

O princípio aí aludido constava da Constituição de 1946, art. 141, $\S 4 .^{\circ}$, e se repetiu nas de 1967 , art. 150 e Emenda n. $1 / 69$, art. 153 , em parágrafo, na mesma ordem o $4 .^{\circ}$.

Cabe, agora, enfrentar o mérito da relação jurídica em apreciação, Objeto do recurso extraordinário, e através do qual os inconformados recorrentes esperam que $o$ eg. STF lhes repare a lesão do direito individual, o qual não thes atendeu o r. acórdão ora impugnada.

3. Penso, data venia, que não se houve com o costumado acerto a douta maioria do eg. Tribunal, como, de resto, bem mostraram os votos vencidos, totalizando 10 , alguns dos quais proficientemente fundamentados.

Com efeito.

Nem as disposições regimentais, nem os preceitos constitucionais pertinentes, antes transcritos $\mathrm{e}$ sobre os quais se armou o dissídio, impõem a maioria absoluta de votos da totalidade do Legislativo, para autorizar a proclamação dos candidatos como eleitos, em primeiro escrutínio.

$\mathrm{O}$ que o art. 31 da Carta Maior estatui e os demais, da Constituição do Estado e Regimento Interno, dispõem, em sequência obrigatória e simétrica, é que as deliberações sejam tomadas por maioria de votos, com a presença da maioria absoluta dos membros que integram o órgão (Câmara e Senado, no plano federal, e Assembleia Legislativa e Câmara Municipal, no plano estadual e municipal, respectivamente).

O mandamento que se contém no citado art. 31 condensa, como tantos outros, princípio organizacional, também chamado básico, essencial ou sensível, ao qual ficaram sujeitos os diplomas de menor alcance, como os dos Estados e Municípios.

$O$ que se permitiu, no particular, ao constituinte local e ao serem versadas normas regimentais, foi, sem desfigurar o standard federal, disciplinar, formalmente, a eleição, como modalidade de deliberação, sem jamais, repita-se, afetar a substância daquele, pertinente a matéria eleitoral, ou seja, o quorum para validar as eleições e o quantum dos votos para apuração do resultado.

E assim sucedeu. A Constituição do Estado, no art. 13, repetiu a determinação da Federal, art. 31. Apenas, em seu parágrafo único, dispôs sobre a forma de exercício do voto, a qual determinou fosse secreta para as eleições e nas hipóteses por ela previstas. A sua vez, o Regimento Interno minuciou o aspecto formal da eleição: requisitos das cédulas, meio de utilizá-las, designação dos escrutinadores, apuração do resultado e sua proclamação, bem como o momento da posse dos eleitos. É o que se lê no art. $15, \mathrm{~b}, \mathrm{c}, \mathrm{d}, \mathrm{e} \S \S 1^{\circ} \mathrm{e} 2^{\circ}$.

Identicamente sucedeu com $o$ Regimento Interno da Câmara dos Deputados, art. $7 .^{\circ}$, e seus respectivos incisos.

$\mathrm{E}$, reitere-se, tinha que, realmente, ser assim, como consequência do 
rígido sistema que, bem ou mal, não vem ao caso averiguar, se iniciou em 1934 e se fez mais sensível com o advento da Carta de 1967, bem como da Emenda n. 1/69, art. 13 e seus incisos, especialmente, o II, e o $\S 1 .^{\circ}$.

A propósito, escreve o eminente Ministro OSWALDO TRIGUEIRO, em seu festejado Direito Constitucional Estadual, FORENSE, 1980, ps. 135/6:

"A partir da Constituição de 1934, entretanto, o direito federal vem impondo aos Estados um tipo de governo cada vez mais padronizado de tal sorte que o poder de autoorganização essencial à existência do regime federal está reduzido a uma "ficção, que não disfarça convincentemente, o unitarismo de um fato que está asfixiando o Estado."

E, em outra expressiva passagem, versando sobre o quorum, afirma, p. 149:

"A aprovação de qualquer proposição, pressupõe, necessariamente, manifestação da vontade dos membros das Casas legislativas, através do voto. A forma de votação é matéria geralmente definida nos Regimentos Internos que dispõem sobre as várias maneiras de colher os votos dos legisladores, voto público ou secreto voto nominal ou voto simbólico, bem como sobre o quorum exigido para as diversas votações. Em seu exagerado casuísmo, porém, a Constituição Federal vigente (art. 31), estabelece que, salvo disposição em contrário, as deliberações de cada Câmara serão tomadas por maioria de votos, presente a maioria dos seus "membros, ... funcionando com a presença da maioria (metade mais um) dos presentes (metade da metade e mais um). uma Assembleia de 35 Deputados, para exemplificar, pode aprovar qualquer proposição por apenas 10 votos favoráveis."

No mesmo sentido é o magistério de MARCELO CAETANO, após enumerar numerosos julgados do eg. STF, de um dos quais destacou síntese feliz e muito expressiva do voto do saudoso Ministro RODRIGUES ALCKMIN, proferido na Representação n. 392/RS. da qual fui Relator e cujo acórdão se encontra publicado na RTJ, vol. 66, ps. 659/71), verbis:

"A obediência aos princípios federais tem sido um standard da constitucionalidade dos dispositivos das leis maiores dos Estados" ("Direito Constitucional", FORENSE, II, p. 301).

Dito destaque veio a ser repetido em ementa a posterior julgado, qual seja, a Representação n. 949$\mathrm{RN}$ e da qual foi Relator o eminente Ministro CORDEIRO GUERRA (RTJ, 81, p. 332).

$\mathrm{Na}$ mesma esteira, PONTES DE MIRANDA ("Comentários da Constituição de 1967, com a Emenda 1, de 1969", ps. 312/3), MANOEL G. FERREIRA FILHO (Coments. à Const. do Brasil, Ed. Saraiva, I, ps. 117 e segs.) e outros.

4. De outra parte, não há como pretender excluir-se da expressão 
deliberações, da qual se serviram os textos constitucionais em comentário, a matéria referente às eleições.

Estas (as eleições) constituem a espécie; aquelas (as deliberações) o gênero. Umas e outras representam a forma pela qual os entes coletivos exprimem a sua vontade, através do voto. CARVALHO SANTOS, em seu "Repertório Enciclopédico do Direito Brasileiro", vol. 5, ps. $159 / 61$, enumera, com detalhes, as formas várias de deliberação através do voto, tanto no Direito Público como no Privado.

Demais, no caso particular do Rio Grande do Sul, o parágrafo único do art. 13 da Constituição dirimiu quaisquer imprecisões, porventura existentes, ao especificar, expressamente as eleições, o que não teria sentido, se das deliberações não cuidasse o artigo ao qual se agregou. Igual dispositivo sé encontra nas constituições dos Estados, além de outros, São Paulo e Pernambuco, arts. $7^{\circ}$, I e II, e $2 .^{\circ}$, parágrafo único, respectivamente.

5. Dessarte, cogente o princípio federal que dispõe sobre as deliberações dos Legislativos, nelas se incluindo, evidentemente, as eleições, todos em perfeita convivência, resta, apenas, apurar o número real de votos do candidato para lhe assegurar a vitória. E outro não pode ser senão o da maioria dos presentes, únicos votantes, satisfeito o quorum deliberativo, ou seja, a presença da maioria absoluta dos componentes do órgão.
6. É mais do que fácil evidenciar esta verdade, de resto já acentuada no desenvolvimento do assunto.

Efetivamente.

Duas são as condições impostas na apuração do resultado da eleição para os cargos da Mesa. A primeira é o quorum para validar o funcionamento do órgão quando se dispõe a tomar deliberações através do voto; e ele é o da maioria absoluta dos integrantes, ou seja o número imediatamente superior à metade dos Deputados, tal como estatui o art. 15, a, do Regimento, cópia fiel do art. 7. ${ }^{\circ}$, I, do Regimento da Câmara dos Deputados.

Ditos instrumentos (Regimentos), explicitaram as expressões das Constituições: "maioria de seus membros" (Federal. art. 31) e "maioria dos membros da Assembleia" (Estadual, art. 13).

A outra condição é que os candidatos que disputam as eleições obtenham a maioria absoluta de votos daqueles que formam o citado quorum, ou seja, dos presentes, pois, os ausentes, como é óbvio, não votam, sequer por ficção ou simbolismo. Para que pudessem se servir desse meio (voto simbólico) era mister que houvesse autorização expressa como sucede no eg. STF, através de seu Regimento Interno quando dispõe, art. $12, \S 3 .^{\circ}$, verbis:

"Considera-se presente à eleição o Ministro, mesmo licenciado, que enviar seu voto, em sobrecarta fechada, que será aberta publicamente pelo Presidente, depositando-se a cédula na urna, sem quebra do sigilo." 
Tal dispositivo inexiste para as eleições nos Legislativos, nem lhe é peculiar, o que importa reafirmar que os únicos votos computáveis são os dos presentes.

É o que, de resto, está expresso no debatido Regimento, art. 15, e, com o acréscimo, "em primeiro escrutínio", ou como estatui o Regimento da Câmara dos Deputados, art. 7. $^{\circ}, \mathrm{XI}$, verbis:

“... maioria absoluta dos votos dos membros presentes para a eleição, em primeiro escrutínio" .

Aqui, as locuções regimentais explicitaram as palavras de que se serviram as Constituições "maioria de votos", iguais em ambas (Federal e Estadual).

7. Acentue-se que a maioria absoluta não constitui uma expressão vaga, imprecisa, indeterminada. Ela exige sempre um padrão de referência, como, de resto, se faz expressa a própria Lei Maior, fonte e manancial primário - e da qual deve brotar a mais pura orientação exegética dos demais preceitos de inferior hierarquia e com os quais se relaciona.

Veja-se o que dispõe o art. 116, ao cuidar da declaração de inconstitucionalidade. A maioria absoluta nele introduzida está determinada com o padrão de referência "de seus membros ou do órgão Especial". Igualmente o art. 144, a, b e c, e III, quando se utiliza das expressões "maioria absoluta de seus membros, ou dos Desembargadores" ao versar o delicado tema da recusa ao acesso dos juizes.
Preceitos outros e muitos poderiam ser trazidos em abono deste entendimento, todos extraídos da Constituição.

Dessarte, as expressões de que se serve o Regimento, art. 15, e, "maioria absoluta", sem qualquer padrão especificativo, por certo que não quis se subentendesse dos integrantes da totalidade do órgão, como explicitou na alínea a, mas a dos presente, pois desses é que passou a versar, após estatuir o quorum deliberativo. Esta, demais é a conclusão que se extrai da interpretação sistemática de todo o dispositivo, a qual não difere, todavia, da sua exegese gramatical, ou seja da norma, em particular exame, a alínea e.

8. E tanto o quorum deliberativo como o critério para apurar o resultado das deliberações somente foram excepcionados, nas hipóteses previstas na própria Constituição. Assim dispõem os arts. 31 e 13, in principio, respectivamente, das Cartas Federal e Estadual. Em sintonia com eles os arts. 40, I, 42, parágrafo único, $48,50,51, \S 3 .^{\circ}$, da última, aos quais correspondem os arts. $14 . \S^{\circ} .^{\circ}, 36,37, \S 3 .^{\circ}, 48,62,73$, $\S 11^{\circ}$, da primeira das Constituições.

E, note-se, o quorum de exceção que, em todas as citadas disposições se especificou, guarda inteira simetria, obediente o estadual ao federal, e tinha que ser, como de resto, tem entendido o eg. STF em numerosos julgados proferidos em Representações (RTJ, 90 , ps. $1 / 11 ; 81$, ps. $332 / 6 ; 57$, ps. $358 / 83 ; 52$, ps. 501/27). 
9. Por fim, acentue-se que, no fundo, em verdade, o sistema deliberativo dos Legislativos não se alterou no regime republicano, desde a Constituição de 1891.

Veja-se a velha mas sempre nova lição de AURELINO LEAL, em sua "Teoria e Prática da Constituição Brasileira", I, 1925, p. 89:

"Quorum parlamentar. Chama-se quorum o número de representantes necessários ao funcionamento de uma Câmara Legislativa. No art. 18 a Constituição estabelece regra geral de um duplo quorum para as votações: presença da maioria dos membros de cada uma das Câmaras, e o assentimento da maioria absoluta destes. Nas votações a maioria absoluta dos presentes é contada dentro da maioria absoluta dos membros da Câmara."

No mesmo sentido é o magistério de AGENOR ROURE ("A Constituição Republicana”, r, 1920, p. 427), JO ÃO BARBALHO, ("Constituição Federal Brasileira", Comentários, 1924, p. 89) e CARLOS MAXIMILIANO "Comentários à Constituição Brasileira", $2^{\mathrm{a}}$ ed., ampliada, p. 298).

Com o advento da Constituição de 1946, o critério não se alterou, como mostra PONTES DE MIRANDA ("Comentários à Constituição de 1946”, II, 1953, p. 238).

A transição, a partir de 1934, e, notadamente a da Carta de 1967, foi apenas pelo aspecto absorvente e determinativo, imposto pela nova ordem federativa, a qual limitou aos Estados o poder de auto-organização, como já foi versado, jamais afetando o critério nas deliberações.

Assim, sem nenhum proveito a invocação do v. acórdão recorrido aos precedentes, referentes a eleições pretéritas da Mesa, exigindo, para os então eleitos, maioria absoluta de votos da totalidade dos Deputados. $O$ fato, por si, não geraria nenhum direito, nem comprometeria critério diverso em eleições futuras.

De qualquer sorte, porém, após o advento da Constituição de 1967, como já ficou sustentado, tal critério não poderia prevalecer, mesmo que viesse a ser aceito pelo Regimento, o que não sucede, porque, em tal hipótese, inconstitucional seria o Regimento, por contrariar o já comentado art. 31 da Carta Maior.

10. A longa, e, por vezes, insistente e reiterada argumentação deduzida evidencia o bom direito sustentado pelo impetrante e os litisconsortes ativos fortes todos nos textos constitucionais da República e do Estado, à sombra dos quais cabe buscar a legítima exegese das normas regimentais pertinentes.

Todavia, o v. aresto do eg. Tribunal não thes reconheceu, negando-lhes o direito líquido e certo que postularam através do mandado de segurança.

11. Para fazê-lo, como se apura da ementa transcrita, fiel ao pensamento da douta maioria, considerou:

a) que, segundo o Regimento da Casa, a "maioria absoluta" para a eleição da Mesa, em primeiro escrutínio, diz respeito à totalidade dos deputados que compõem o Legislativo; 
b) que tal conclusão exegética decorre do próprio conceito de "maioria absoluta" que está sempre relacionada ao todo, a menos que haja restrição expressa e esta seria a tradição da Assembleia;

c) que a regra regimental assim interpretada não afronta os arts. 31 e 13 das Constituições Federal e Estadual que preveem "maioria simples" para quaisquer deliberações, menos as administrativas, onde se incluem as eleições, disciplinadas pelo poder de organizar-se, segundo outorga também constitucional, art. 30 .

12. Considero que, em assim procedendo, o aresto recorrido deu ensejo ao recurso extraordinário para o eg. STF, com seguro embasamento no art. 119, III, a e c, da Constituição Federal. Quanto à primeira alínea porque contrariou o seu art. 31, combinado com o art. 13 e seus incisos, especialmente o II, e o $\S 1$. ; e quanto à segunda (letra c), eis que $o$ ato impugnado foi, desde a petição inicial, e até antes dela, perante o próprio Legislativo, ao ensejo da eleição, contestado ante a citada Carta, com base nos já referidos artigos, e, não obstante, o acórdão julgou válido o ato incriminado.

Realmente. Não esteve bem inspirada a honrada maioria do col. Colegiado local.

Como já se fez acentuar, a regra que se contém no art. 31 da Constituição Federal, ao qual corresponde o art. 13 da Estadual, é cogente aos Estados, cujo poder de auto-organização ficou "limitadíssimo", na expressão do
Ministro OSVALDO TRIGUEIRO, em passagem já transcrita, afetando até os lindes dos Regimentos Internos dos Legislativos.

E ao fazê-lo, usando a expressão "deliberações", compreendeu a todas, salvo aquelas que ela própria, constituição, explicitou, como, de resto, o fez, de forma expressa, a Constituição do Estado, em seu art. 13, melhor elucidado, no particular das eleições, através de seu parágrafo único, como também já foi longamente demonstrado. Assim, seja no pertinente ao poder regimental de auto-organizar-se, seja na função mais ampla de administração, a depender de deliberação do órgão, seja, enfim, no âmbito legiferante, tudo segue a regra segura e límpida do citado art. 31, salvo nas expressas exceções consagradas no texto constitucional, também já comentadas, e nas quais não se incluíram as eleições da Mesa.

Orientando-se diversamente, por certo, o acórdão contrariou e de frente o comentado art. 31 , ao qual se pode conjugar, como reforço, o art. 13 , e seus incisos, notadamente o II e o $\S 1 .^{\circ}$.

É o suficiente para justificar só por si o conhecimento do recurso e o seu provimento, como bem o situou e propugnou a petição de recurso extraordinário, a qual tem inteiro apoio nas considerações anteriores deste parecer fundadas na jurisprudência da eg. Corte Suprema, acorde com a melhor doutrina.

Mas não é só. $O$ excepcional oferece igual consistência quanto ao segundo fundamento, letra $\mathrm{c}$. 
$O$ ato do Senhor Presidente da Assembleia ora impugnado é "ato do governo local", a que se refere a mencionada letra $\mathrm{c}$, no conceito que the atribuem os doutrinadores (AMARAL SANTOS. "Primeiras Linhas de Direito Processual Civil", $3 .^{\circ}$ vol., 3. ${ }^{a}$ ed. Saraiva, n. 825 , ps. 156/7; JOSÉ AFONSO DA SILVA, Recurso Extraordinário no Direito Processual Brasileiro, RT, 1963, n. 99 , p. 224) .

E dito ato, contestado, nas circunstâncias já referidas, perante $\mathrm{o}$ art, $31, \mathrm{c} / \mathrm{c}$ o art. 13 e seus incisos especialmente, o II e o $\S 1^{\circ}$, não logrou sucesso perante o eg. Tribunal, o qual deu por sua validade.

Entretanto, a arguição de inconstitucionalidade ao aludido ato é mais do que razoável, o que justifica o conhecimento da irresignação derradeira, nos termos da Súmula n. 285. E ainda, o seu provimento, pelas razões constantes da petitória recursal e amplamente desenvolvidas neste parecer.

13. Dessarte, seja pelo primeiro, seja pelo segundo dos fundamentos deduzidos, ou por ambos, o que seria mais coerente, é de esperarse o conhecimento e o provimento do recurso extraordinário por essa col. Suprema Corte, deferindo-se o mandado de segurança, nos próprios termos do pedido, fazendo, assim, como sempre, a melhor Justiça.
14. Por último é de notar-se que o r. julgado impugnado, ao impor condenação em honorários de advogado, em ação de mandado de segurança, dissentiu da jurisprudência do eg. STF, cristalizada em sua Súmula, verbete n. 512, o qual foi mantido mesmo após o advento do vigente C. Pr. Civ., como se vê de julgados vários de ambas as Turmas (RTJ, 95, ps. 404 e 428), onde são invocados precedentes outros.

Justifica-se aqui o conhecimento e provimento do recurso com assento na letra $\mathrm{d}$ do permissivo constitucional." ${ }^{23}$

Da mesma forma; parecer que enfrentou questão pouco versada na doutrina e na jurisprudência acerca dos limites do poder do Tribunal de excluir candidato aprovado no concurso para a magistratura.

A respeito, anotou o Ministro Thompson Flores, invocando a sua longa experiência de magistrado, verbis:

"Versa a espécie sobre o citado ato administrativo, na sua fase primeira, antes da indicação dos concorrentes aprovados e classificados para sua regular nomeação.

Em dita fase, o procedimento concursal divide-se em outras tantas, as quais integram o que os autores denominam fases progressivas ou 
sucessivas (O. Ranelletti, in Le Guarentigie della Giustizia nella Pubblica Ammnistrazione, $4^{a}$ ed., Dott. A. Giuffrè Editore, 1934, p. 117, n. 76). Assemelha-se o concurso a uma espécie de escada, cujos degraus têm área própria $\mathrm{e}$ devida destinação. Por eles, degraus, vai ascendendo o concorrente, conquistando, em cada um deles, um relativo direito subjetivo.

Parecem-me os concursos para provimento dos cargos públicos, especialmente os dos juízes, de maior qualificação, às licitações nas concorrências públicas, como fazem notar os tratadistas da matéria. Deles, limito-me a indicar, por sua habitual clareza, o sempre consultado Professor Hely Lopes Meirelles, em várias de suas obras, inclusive Pareceres, e das quais destaco seu considerado Direito Administrativo Brasileiro, $5^{\text {a }}$ ed., ps. 396 e seguintes, e a clássica Licitação e Contrato Administrativo, $3^{a}$ ed., ps. 117 e seguintes, todas elas ilustradas com julgados, especialmente do Egrégio S.T.F.

4.1. O que brota da simples leitura do edital em comentário é o que acaba de ser afirmado. Sua clara linguagem e disciplinação, referente às várias fases do certame, mostra a sua racionalidade, permitindo verificar, como nas concorrências públicas já citadas, que, cumpridas que sejam pelo concorrente, completamse, ultimam-se, a elas não mais se retornando. Certamente não se afirmará que gozam, cumpridas, do poder da res judicata, mas, porque definitivas, não se reabrem.

\section{Com efeito.}

$O$ edital que rege o presente concurso, $\mathrm{n}^{\circ} 24 / 83$, é longo, detalhado e bem sistematizado. Proporciona, assim, fácil compreensão. É penoso para o concorrente pelas exigências muitas que the impôs cumprir.

5.1. Começa ele disciplinando o pedido de inscrição provisória, $\mathrm{n}$. 1, seguindo-se a chamada "Fase Preliminar", n. 2. Nessa se realiza a nominada "prova escrita preliminar", dividida em duas partes devidamente esclarecidas, ns. 2.1 a 2.6.

Aos que forem nela aprovados, proporciona-se o direito de requererem a "Inscrição Definitiva", n. 3.1 , impondo ao requerente, além de petição detalhada, a apresentação de novos documentos, n. 3, alíneas a e e.

Convém, desde já, sublinhar o que estatuem seus subitens, 3.2 a 3.4.

Dizem eles, verbis:

“3.2 O Órgão Especial do Tribunal de Justiça, em sessão secreta decidirá, conclusivamente, e por livre conviç̧ão, a respeito da admissão dos candidatos aprovados na prova escrita preliminar, atendendo às suas qualidades $e$ aptidão para o cargo.

3.3 A Comissão colherá informes sobre os candidatos, procedendo à sindicância da vida pregressa e investigação social.

3.4 Os candidatos aprovados na prova preliminar serão submetidos a entrevista com a Comissão de Concurso".

5.2 Sucessivamente seguem-se as "Provas Escritas", n. 4, disciplinadas 
nos subitens 4.1 a 4.6; "Prova Oral", n. 5.1; a de "Aferição dos Títulos", n. 5, integrada pelos subitens 5.1, alíneas a a n, e 6.2 a 6.5 ; as dos "Exames de Saúde, Física e Mental e o Psicotécnico", n. 7.

Atinge-se, assim, a cognominada "Nota Final", n. 8; e, a derradeiro, o "Julgamento do Concurso", n. 9. Encerra-se com os esclarecimentos do prazo de "validade" do concurso, n. 10. Segue-se a da "Nomeação", n. 11, "Observações Gerais", ns. 12 a 12.5; e, para encerrar, o de n. 13, o da "Comissão de Concurso".

6. A requerente submeteu-se a todas elas e as satisfez, cumpridamente, tanto que atingiu àquela da aprovação e subsequente classificação, cabendo-lhe o $51^{\circ}$ lugar, em lista que foi divulgada.

6.1 Foi aí que aconteceu o pior, resultando, após dita divulgação, omitido o seu nome ao ser publicada a relação no D.O. de 22.05.85. Continua ela a ignorar o motivo da exclusão, ainda que, em reclamo administrativo, o propugnasse, sendo ele indeferido, o que lhe obstou qualquer gênero de defesa da presuntiva ocorrência da falta, a qual há de ser grave, face ao grau de penalidade que lhe foi imposta, com o elenco de efeitos, os mais variados e negativos, quanto à sua personalidade.

Observo, data venia, que em épocas passadas, como já salientei atrás, diversa era a orientação da Colenda Corte.

Vigilante sempre como me impendia o ser, como os demais Colegas, estive sempre atento a repelir concursandos sobre cuja idoneidade moral pairasse dúvida. $\mathrm{E}$ isto desde os momentos iniciais de análise da inscrição. Nessa fase, fazendo-o discricionariamente, como já era admissível (M. Petrozziello, in Il Rapporto di Pubblico Impiego, Società Editrice Libraria, 1935, p. CLI). Mas, note-se, procedia o Eg. Tribunal diversamente quando a acusação ocorria em fases posteriores do concurso, quaisquer que fossem elas, "mesmo à altura posterior a da aprovação e prestes à indicação dos candidatos já classificados. Ouvia-se, nesse ínterim, o acusado para que a conhecesse, oferecesse defesa e, se o quisesse, apresentasse provas. Em sessão secreta, o Tribunal apreciava o ocorrido e decidia, por maioria de votos, pela sua procedência ou não. Excluía-se o concorrente na primeira hipótese, ou mantinha-se-o no lugar conquistado na segunda. $E$ assim era o seu procedimento habitual, repetido e unânime, isso porque seu ato administrativo era, manifestamente, regrado, em harmonia com os termos da lei e em consonância com as garantias que a Constituição assegurava ao candidato.

Em precioso estudo intitulado "L'Esclusione dai Pubblici Concorsi e L'art. 51 della Costituzione", publicado na renomada Rivista Trimestrale di Diritto Pubblico, 1952, conclui, em significativo trecho, Giovanni Miele, verbis:

"Quindi, di fronte a un atto amministrativo lesivo di un diritto o interesse legittimo v'è sempre la possibilità della tutela 
giurisdizionale; ma, poichè la lesione di un diritto o interesse legittimo può essere in relazione ai motivi determinanti dell'atto, la persona cui il provvedimento si riferisce deve essere messa in grado di conoscerli. Ne consegue allora, che, allo stesso modo in cui gli altri elementi rilevanti per la legittimità dell'atto risultano o debbono risultare dall'atto stesso, come la competenza, l'osservanza delle forme e della procedura, la menzione che è stato udito un parere obbligatorio, così parimenti deve risultare dall'atto la specificazione delle ragioni giustificative che siano giuridicamente rilevanti per la legittimità di esso".

7. Considero, por isso, data venia, que mal orientada esteve a Egrégia Corte ao proferir a deliberação com respeito à requerente.

8. A análise do edital do concurso não autoriza, data venia, a exclusão comentada.

Realmente, e cabe insistir.

Em duas oportunidades o respeitável Órgão Especial do Tribunal de Justiça examina e decide a respeito da idoneidade do concorrente: primeiramente, na chamada "Inscrição Definitiva", ns. 3 e 3.2; posteriormente, a segunda das fases para o exame da honorabilidade do candidato é a do "Julgamento do Concurso", n. 9, e, em especial, n. 9.1.

Convém ter presente essas normas indicadas, as quais me abstenho de transcrever para não estender em demasia o presente pronunciamento, posto que as recordando a cada passo, pois elas são decisivas para apreciar o procedimento recursal.

8.1 Na primeira fase, o poder da Corte é discricionário, tal como o conceitua a doutrina e repetem os julgados dos Tribunais.

$\mathrm{Na}$ segunda das fases indicadas seu poder é regrado, como em qualquer outro momento, até o da posse do candidato. $\mathrm{E}$, ocorrendo a indicação da falta, o comportamento do Tribunal é diverso, obrigado que está a convocar o acusado, revelando-lhe em que consiste a inculpação.

Oferece-lhe, então, oportunidade de defesa e até de produção de provas. Secretamente as examina e decide, já não mais de plano e conclusivamente, como sucede quando dispõe do poder discricionário, posto que com base no livre convencimento, e conclui por sua procedência ou não, com os efeitos daí emergentes e já considerados, como é próprio do ato regrado.

O cuidado que deve orientar o Tribunal no exame da honorabilidade dos candidatos à judicatura é questão que me dispenso de considerar, pois é conhecido o alto proceder com que sempre atua a mais alta Corte de Justiça local.

Ora, se a honradez do cidadão merece integrar sua personalidade, admitindo presuntivamente sua ocorrência, com mais forte razão a do funcionário público que dispõe de parcela de autoridade, notadamente o juiz, que vai julgar os atos de seus jurisdicionados, nos mais variados 
sentidos, seja na família, como marido e pai; seja no ambiente de trabalho, quando pratica tantos atos administrativos, no exercício da função, quanto na tela criminal, quando aplica as mais graves sanções.

São os magistrados como a mulher de César, sejam, em realidade, honrados, mas parecerem o ser, como requer a comunidade onde irão praticar o seu delicado ofício.

8.2 Não foi em vão que o Egrégio Tribunal de Justiça, ao ser procedida a adaptação da Constituição do Estado à Carta Federal, propôs - e a Colenda Assembleia Legislativa aceitou - a adaptação que constou do novo texto constitucional do Estado, em seus arts. 109, V, e 115.

Todavia, o Governador representou à Procuradoria-Geral da República arguindo a inconstitucionalidade dos preceitos citados, além de muitos outros.

Tomou dita Representação o $\mathrm{n}^{\circ}$ 749 e foi julgada improcedente (Representações no S.T.F., t. II, ps. 206 e seguintes; RTJ, vol. 50, ps. 738 e seguintes).

Criou-se, na ocasião, a figura do Juiz Adjunto, estatuindo-se que só se tornaria Juiz de Direito aquele que, depois de ultrapassado o prazo de dois anos da investidura no cargo para o qual havia prestado concurso apenas nas provas intelectuais, prestasse, agora, decorrido o biênio, concurso de títulos.

A excelência do novo sistema, salientei então, e com ligeiras modificações de forma, consta hoje da Carta local, Emenda n. 7.

8.3 Invoco o precedente para mostrar que a vigilância dos Órgãos Disciplinares não se finda com os concursos, sobre os quais se discute neste mandado de segurança. Prorroga-se, ela, pela vida inteira dos magistrados em atividade. E ela se torna quão mais fácil, proveitosa e salutar ao Poder Judiciário quando antes de adquirir o magistrado as prerrogativas de juiz vitalício. Ela já ocorria, há anos, no Estado de São Paulo, no extinto Estado da Guanabara, onde o prazo era de quatro anos, e, pelas virtudes do sistema, outras unidades da federação o aceitaram.

É que, até então, precárias eram as condições para examinar de requisitos outros a satisfazer pelo juiz, além daqueles comprovados no concurso de provas.

Os que versaram os predicamentos impostos aos bons juízes os destacam em suas obras, votos e artigos de doutrina (Mário Guimarães, O Juiz e a Função Jurisdicional; identicamente o salientou o julgado em M.S. n. 2.267, em 30.11.53, publicado na R.D.A., v. 60 , ps. 120/3). O Diagnóstico elaborado pelo S.T.F. sobre a Reforma do Poder Judiciário realizada em 1977, quando eu exercia a Presidência daquela Alta Corte, depois do estudo meditado dos mais de noventa volumes com proposições dos Tribunais e mais aquelas que constam hoje de seus arquivos, o salienta. Igualmente o faz a Proposta de Reforma do mesmo Estatuto, 
em 11.05.56 (in R.D.A., v. 46, ps. 54 e seguintes).

Cabe ler, para melhor ilustrar, todo o debate que se fez na Egrégia Suprema Corte quando, larga e profundamente, houve por bem rejeitar a inconstitucionalidade da representação, no particular, para se verificar a importância que aquela Corte emprestou aos predicamentos impostos aos juízes (Rp. n. 749, in R.T.J., v. 50, p. 738 e seguintes).

8.4 Essas observações que acabam de ser feitas para bem evidenciar a exigência mais que indórmita que se reclama quanto aos juízes e dos Órgãos Superiores que sobre eles têm jurisdição, notadamente disciplinar, - faltas de ordem moral e social acaso ocorrentes, ao menos a eles imputadas, impõe-se, como não poderia deixar de ser, sob pena de contrariar a Constituição, assegurarlhes toda defesa, dependendo os procedimentos adotados dos direitos subjetivos que já dispõem, tal como estatuem os diplomas citados. $\mathrm{E}$ acentue-se que sempre operase veladamente, discretamente $\mathrm{e}$ até, por vezes, secretamente, para assegurar, a cada passo, a discrição na sua apuração, em prol do Poder Judiciário.

Falam por si alguns julgamentos ocorridos na Suprema Corte, muitos dos quais participei, como se vê das publicações já feitas (R.T.J., v. 85, ps. 986 e segs.; v. 86 , ps. 619 e segs.; v. 89 , ps. 846 e segs.; e v. 109 , ps. 48 e segs.).

9. In caso, a requerente foi excluída, cancelando-se a sua inscrição sumariamente, nas circunstâncias já por vezes várias sublinhadas, quando, até então, sua inscrição prevaleceu para justificar as muitas provas que lhe sucedeu.

Procedeu a Egrégia Corte como se dispusesse do poder discricionário que já não possuía, o qual era evidentemente regrado. Obrigado, então, ao exercício de atividade sujeita à disciplina legal, seja como se deduz das disposições constantes do edital já comentado, as quais condensam toda a legislação pertinente, seja da própria Constituição, ao calor das quais devem ser consideradas e obedecidas.

$9.1 \mathrm{Na}$ espécie já tão examinada, omitindo-se o Colendo Tribunal em proporcionar à requerente, como lhe cumpria, o direito de defender-se, praticou ato administrativo eivado de nulidade mortal, tal como dispõe o Código Civil, art. 145, IV, aplicável também aos atos administrativos, na lição unânime dos autores, como já salientava há anos o Mestre saudoso Ruy Cirne Lima (Princípios de Direito Administrativo, $5^{a}$ ed., 1982, p. 94), combinado com o art. 153, §§ 15,21 e $4^{\circ}$, da Constituição Federal de 1969.

Outro não é o ensinamento de Raphael Alibert, em sua obra clássica Le Contrôle Juridictionnel de L'Administration, Paris, 1926, p. 221/2, verbis:

"Le vice de forme en droit administratif est une nullitté qui provient de la violation de formes édictées par les lois et règlements. Cette nullité existe sans texte et elle est en principe absolue. 
Les formalités administratives ne sont pas des procédures de pure forme dont il serait loisible à l'administration d'éluder l'accomplissement. $\mathrm{Ce}$ sont des garanties accordées aux administrés; elles sont pour eux la contre-partie des pouvoirs exorbitants de l'administration, ainsi qu'une assurance contre le risque des décisions hâtives, mal étudiées et vexatoires. Elles sont en principe d'ordre public".

9.2 É lamentável que a Egrégia Corte tenha procedido contra a lei, realizando $o$ ato impugnado, deslembrada de assegurar o direito de defesa à concorrente, máxime nas circunstâncias em que o fez. Dito direito é inato à criatura humana.

$\mathrm{O}$ próprio Deus, o mais sábio $\mathrm{e}$ justo dos juízes, assim o entendeu, apesar do seu poder total, desde o princípio do mundo. Externou-o ao ser cometido o primeiro homicídio ocorrido sobre a Terra, quando Caim, levado pela inveja, matou seu irmão Abel.

São palavras do Senhor, segundo a Bíblia Sagrada, Genesis, cap. 4, n. 9:

"E o Senhor disse a Caim: onde está teu irmão Abel ao que Caim respondeu. Eu não sei. Acaso sou eu guarda do meu irmão?"

E consta do mesmo livro e capítulo, n. 10:

"Disse-lhe o Senhor: Que é o que fizeste? A voz do sangue de teu irmão clama desde a terra até mim."

E, só então, o Senhor o puniu. Não se animou, o maior Juiz, a aplicar-lhe a sanção, como o fez, sem ouvi-lo para que se defendesse.

E assim seguiu-se na marcha das gerações.

Entre nós, o direito de defesa jamais foi ignorado e deixou de ser reconhecido. Desde o regime republicano, conforme a Constituição de 1891, resultou expresso, art. 72 , § 16. Integrou, ele, as demais Constituições que àquela se seguiram: 1934, 1937, 1946, 1967 e Emenda $\mathbf{n}^{\circ}$ $1 / 69$, art. $153, \S 15$, em pleno vigor.

9.3 Por certo os fatos mais comuns ocorrem nos procedimentos criminais. Mas sempre se reconheceu a necessidade de observar-se o direito de defesa nos processos administrativos, quando do seu exame se imputa falta grave ao servidor. No presente procedimento, a toda evidência, ele é de aplicar-se, eis que trata de processo semelhante ao qual incidem normas decorrentes do Direito Administrativo.

9.4 Cabe assinalar que mesmo no regime revolucionário instaurado no País em 1964, os Atos Institucionais, embora sobranceiros à própria Constituição, reconheceram o direito de defesa, deixando-o expresso. Assim ocorreu com o primeiro deles, AI n. 1/64, art. $7^{\circ}, \S 4^{\circ}$, com a regulamentação que lhe atribuiu o Decreto $\mathrm{n}^{\circ}$ 53.897, de 27.04.1964, art. $5^{\circ}$ (in R.F., v. 206/434), ao impor graves sanções.

No S.T.F. concorri com meu voto para anular diversas sanções impostas com base no citado art. $7^{\circ}, \S 4^{\circ}$. E o fundamento central das nulidades dos procedimentos referidos assentou na 
falta de audiência dos imputados, como o impunha a citada legislação. Destaco de tais julgamentos os primeiros deles, publicados na R.T.J., v. 47/211; v. 50/67; e v. 53, ps. 120 e 379 .

Inegavelmente $o$ princípio em comentário, direito de defesa, aplica-se ao procedimento do concurso quando, é certo, ocorre acusação sobre o concorrente já admitido em definitivo, depois de procedido o seu respectivo exame, discricionariamente, pelo Tribunal. Certo ele não vem expresso, apesar dos detalhes introduzidos na regulamentação do concurso, seja, no edital, seja em leis outras a ele referentes.

Dito direito, que o Padre Vieira acentuava em seus "Sermões" ser "sagrado", está implícito na sua disciplinação, eis que a Constituição sobre ele incide, projetando-se com toda a força e intensidade.

Cabe, aqui, invocar a lição do saudoso mestre Pontes de Miranda, em seus Comentários à Constituição de $1967 \mathrm{c} / \mathrm{c}$ a Emenda n ${ }^{\circ} 1 / 69$, t. $4^{\circ}$, p. 624, "c", verbis:

"Nenhuma lei brasileira pode ser interpretada ou executada em contradição com os enunciados da Declaração de Direitos, nem em contradição com quaisquer outros artigos da Constituição de 1967; porém alguns dos incisos do art. 153 são acima do Estado, e as próprias Assembleias Constituintes, não os podem revogar ou derrogar. Tais incisos são os que contêm declaração de direitos fundamentais supraestatais".

10.1 Certamente se dirá que, em sendo assim, mesmo na primeira fase do certame, havendo dúvida sobre a idoneidade do concorrente, o direito de defesa tinha de lhe ser reconhecido. Sem qualquer razão o argumento por que opera, então, o Tribunal, discricionariamente, com o poder que sempre se lhe reconheceu e sempre constou das leis e regulamentos dos concursos. $E$ inexiste, ademais, qualquer direito do candidato de ser admitido naquele instante prefacial do respectivo procedimento. Jamais daí por diante, quando o seu pedido de inscrição já fora reconhecido como definitivo, tal como ocorreu com a requerente." 24

A contenda foi solvida pelo Supremo Tribunal Federal, acolhendo o parecer no RE $\mathrm{n}^{\circ}$ 116.070-RS, publicado o acórdão na RTJ 129/883.

Ao analisar a prescrição da ação de cobrança de honorários advocatícios, teve oportunidade de expor os seus reconhecidos conhecimentos de direito civil, concluindo, verbis: 


\section{“A) CONSIDERAÇÕES NECESSÁRIAS}

1. O título de crédito que embasou todos os procedimentos dos quais se serviram os consulentes para receberem seus honorários como advogados, foi o contrato que avençaram com Lídio Floriano Melo, através de escritura pública lavrada em 31-5-1952.

Com ele, contrato, instruíram a primeira das ações, a executiva, ajuizada contra Lídio em 29-11-1969; dele se serviram, após, para se habilitarem na sobrepartilha da estância "Duas Marias", iniciada em 12-9-1974; e do mesmo instrumento se serviram para a demanda que intentaram contra os herdeiros de Lídio, a qual findou em acordo, homologado pelo juiz; e foi ele, ainda, que veio a alicerçar a ação sumaríssima, recentemente apreciada, em segunda instância, como ficou referido no capítulo anterior.

2. Das cláusulas avençadas no contrato em questão, entre outras, estatuíram as que impende serem transcritas, e que são as seguintes:

“[...]

QUARTA - Em remuneração de tais serviços o outorgado LYDIO FLORIANO MELLO, por bem desta escritura e na melhor forma de direito, e, na qualidade de testamenteiro no exercício da testamentaria, se obriga a pagar aos outorgantes seus advogados, trinta e cinco por cento (35\%) calculado sobre o líquido a ser apurado. Considera-se líquido, o saldo resultante do valor real da estância “Duas Marias”, acrescido da importância correspondente a indenização devida pela ocupação do imóvel e durante todo o tempo, desde as escrituras de venda ou cessão de direitos hereditários até final liquidação - deduzidas as parcelas correspondentes ao preço, mais os juros moratórios e quaisquer benfeitorias no mesmo prédio rural, realizadas pelo comprador.

QUINTA - Entende-se rescindido de pleno direito o presente contrato de honorários de advogados e sujeito, em consequência, o outorgado LYDIO FLORIANO MELLO, ao integral pagamento dos mesmos honorários advocatícios:

a) $[\ldots]$

b) si esta, sem justa causa, revogar os poderes já outorgados aos mesmos;

[...]

OITAVA - Os honorários serão devidos aos advogados ora outorgantes, ressalvada a hipótese da referida cláusula quinta e suas letras - logo após a terminação dos serviços judiciais a que se obrigaram e que deverão realizar sem dolo e nem malícia e deverão ser pagos, anual e parceladamente até final liquidação, com o saldo dos arrendamentos produzidos pelo mesmo imóvel rural.

Entende-se saldo, a importância líquida da renda, descontadas as quantias atinentes ao pagamento de impostos e taxas relativos e incidentes sobre o mesmo campo; [...]." 
3. Através delas, as cláusulas, em conjugação com o mandato recebido, impunha-se aos consulentes a missão de usarem dos procedimentos adequados para fazerem retornar ao acervo hereditário de Narciso Melo a estância "Duas Marias", bem como a ele, espólio, incorporarem a indenização que apurassem em liquidação, decorrente da ilegal ocupação daquela área, ou seja, desde a posse até sua efetiva restituição. Daí os precisos termos do pedido, constante da parte derradeira petição inicial, da ação proposta, de nulidade da alienação, anteriormente transcrito, mas que convém repetir, verbis:

“... devolverem ao monte da herança a estância de criar denominada "Duas Marias", devendo, ademais, repor ao monte o valor correspondente à indenização pela fruição e ocupação do prédio rústico, acrescido dos juros legais moratórios, descontada a quantia relativa ao total do preço pago, acrescida, também, de juros legais, tudo na conformidade do que for apurado em liquidação."

4. Por isso, os honorários contratados, em princípio, somente, seriam devidos com o cumprimento integral daquela pretensão, acolhida, sem restrições, pelo julgado final do Eg. Supremo Tribunal Federal.

5. Todavia, obstados ficaram os consulentes de levarem a bom termo o seu encargo, pela atitude do contratante, Lydio, bem como dos demais herdeiros que, posteriormente, lhes haviam outorgado procuração para a execução amigável do acórdão referido, revogando, imotivadamente, seus mandatos.

6. A partir de então, ou, mais precisamente, quando fossem notificados dos atos revogatórios, dispensados estavam os consulentes da atividade profissional a que se haviam comprometido, sem prejuízo do direito de receberem a totalidade dos honorários profissionais contratados, tal como dispõe a cláusula quinta, letra $b$, do contrato, antes tamibém transcrita.

7. Sucede que o contrato de honorários em questão, tendo em vista as condições estipuladas, caracterizase como especial, nominado pelos doutores, como contrato cotalício ou quota-litis. Com base nele, o quantum ajustado somente dará direito a seu recebimento, quando ocorrer lucro para o cliente, ou seja, quando a demanda proposta for julgada procedente, ainda que em parte. E é, exatamente sobre o líquido apurado que incidirão as percentagens ajustadas, proporcionando sua paga (PONTES DE MIRANDA, Trat. de Dir. Priv., VI, 1955, p. 151).

8. Asșim, embora os consulentes se tornassem titulares do direito à totalidade dos honorários contratados, sem necessidade de prosseguirem, como advogados, na execução do acórdão final do $\mathrm{Eg}$. Supremo Tribunal Federal, face à revogação do seu mandato pelos outorgantes, não poderiam eles, os consulentes, exercitá-los, desde logo; $\mathrm{e}$ isto porque a percentagem a eles referentes, incidiria sobre o líquido 
a ser apurado, definido, dito líquido, como o valor real da estância "Duas Marias", acrescido da importância correspondente à indenização devida pela ilegal ocupação do referido imóvel, durante todo o tempo, desde as escrituras de venda ou cessão de direitos hereditários, até final liquidação, deduzidas as parcelas correspondentes ao preço, mais os juros moratórios e quaisquer benfeitorias no mesmo prédio rural, realizadas pelo comprador, tal como dispõe a cláusula quarta, antes igualmente transcrita.

9. Tudo, pois, está a mostrar que o exercício do direito assegurado aos consulentes, de receberem seus honorários profissionais, estava a depender de dois acontecimentos futuros, quais sejam: $1^{\circ}$ ) a verificação do valor real da estância a devolver; e $2^{\circ}$ ) a liquidação do valor da indenização devida pela sua ocupação, como ficou explicitado anteriormente. Eram fatos jurídicos porvindouros, inexistentes à época da revogação do mandato, e, só ocorridos anos após, o último dos quais, recentemente, com a prolação da respectiva sentença de liquidação.

É a aplicação do disposto, respectivamente, nos arts. 114 e 118 do Cód. Civil, verbis:

"Art. 114. Considera-se condição a cláusula, que subordina o efeito do ato jurídico a evento futuro e incerto.

[...]

Art. 118. Subordinando-se a eficácia do ato à condição suspensiva, enquanto esta se não verificar, não se terá adquirido o direito, a que ele visa."

A propósito, com propriedade, acentuou o eminente e saudoso Min. Orosimbo Nonato, ao votar, como relator, no $\mathrm{RE} \mathrm{n}^{\circ} 13.386$, do D.F., in Rev. For., 132, p. 420:

“...É certo que, na pendência da condição suspensiva, a obligatio não se torna exigível, nihil interim debetur a condição suspensiva impede antes de seu implemento, que $o$ ato desvele sua eficácia (vede Espínola, in Manual Lacerda, vol. III, parte $2^{a}$, p. 294).

Como disse Coviello, "il negozio esiste anche prima s'avveri la condizione, ma la sua efficacia rimane sospesa" (Man. di Dir. Civ., $\S 134$, p. 426).

O que então ocorre é uma expectativa, posto que qualificada, de direito, que se adquirirá com o seu implemento."

Anteriormente, no mesmo sentido, já decidira o Eg. Supremo, ao julgar o Ag. de Pet. 4.192 do D.F., em 05-51926, do qual foi relator o eminente e saudoso Min. Edmundo Lins (Rev. de Direito, 83, p. 369/72). E, mais recentemente, no $\mathrm{RE} \mathrm{n}^{\circ}$ 83.942, em 19-10-1976, do qual foi relator o eminente Min. Cunha Peixoto (apud M. NOELI FOL. Direitos do Advogado do Paraná, p. 295/304).

Esta é, ademais, a lição dos nossos tratadistas. Além de ESPÍNOLA, citado inicialmente, cabe acrescentar: CLÓVIS (Cód. Civ. Coment., I, 1931, p. 365-6); CARVALHO SANTOS (Cód. Civ. Bras. Inter., III, 1937, p. 
51-63); CAIO MÁRIO (Inst. de Dir. Civ., I, 1978, p. 487-93) e outros.

Inobstante, PONTES DE MIRANDA, cuidando, especificamente, dos contratos cotalícios de honorários, como, no caso, preleciona, in Trat. de Dir. Priv., VI, 1955, p. 151:

“... Nos contratos cotalícios de honorários, em que a percentagem há de ser paga afinal, a pretensão somente nasce quando se procede à liquidação. Não há, aí, condição suspensiva; há direito e, ao ser feita a liquidação, pretensão."

10. Pouco importa que, em 2911-1969, após a revogação dos mandatos, tenham os consulentes ajuizado contra Lídio Floriano de Melo, ação executiva visando a cobrar seus honorários.

É que, com o julgamento final da causa, tal procedimento tornouse ineficaz; com ele, pois, não se podendo operar para o desprezo da condição suspensiva já comentada e constante do contrato.

\section{B) DA PRESCRIÇÃO DO DIREITO DE AÇÃO}

1. Como ficou inicialmente esclarecido, a Cda. $1^{\text {a }}$ Câmara Cível do Tribunal de Alçada, ao julgar a apelação interposta pelos réus vencidos, herdeiros nomeados de Narciso Melo, houve por bem decidir:

a) por unanimidade, rejeitar as prejudiciais suscitadas pelos apelantes, de carência de ação e coisa julgada; e

b) por maioria, acolher a de prescrição do direito de ação, também por eles arguída.
2. Conquanto uniformes na conclusão, reconhecendo a prescrição, dissentiram os votos vencedores na sua fundamentação.

Operou o do relator com o contrato de honorários, e dele extraiu subsídios para reconhecer que o marco inicial do prazo da prescrição era o da data do julgamento final proferido pelo Eg. Supremo, ou seja, 25-11-1963, posto admitisse que, ainda que fosse ele 29-11-1969, consumada, de qualquer sorte, estaria a prescrição, sem apreciar os motivos que, porventura, tivessem interrompido o prazo quinquenal.

Mais completo se fez o voto do terceiro juiz, Dr. Lio Schmitt, após seu pedido de vista dos autos.

Embora reconhecesse ser encargo do Espólio pagar os honorários dos advogados contratados pelo testamenteiro, concluiu, inobstante, que não estava dito acervo hereditário vinculado às cláusulas do contrato ajustado apenas entre o testamenteiro e os profissionais, dado que sobre dito contrato não foram ouvidos nem o inventariante, nem os herdeiros, nem ocorreu, ademais, homologação judicial.

Por isso, concluiu que o direito dos advogados de cobrarem seus honorários defluiu da data em que se verificou a revogação do mandato, quando, consequentemente, se iniciaria a contagem do prazo para prescrição. Protraiu-o, todavia, para 29-11-1969, data do ajuizamento da primeira ação de cobrança, em questão, ausente que se fizera a notificação do ato revogatório. 
$\mathrm{E}$, como repeliu qualquer causa suspensiva ou interruptiva do prazo prescricional, aceitou sua consumação.

3. Com todas as vênias dos nobres juízes que formaram a maioria, no julgamento rememorado, tenho que não foram bem inspirados ao acolherem a prejudicial de prescrição.

É o que se pretende demonstrar a seguir.

4. Como preleciona CÂMARA LEAL, em sua clássica monografia Da Prescrição e da Decadência ( $p$. 21 e segs.), um dos fundamentos nucleares do instituto da prescrição assenta, desde o Direito Romano, na omissão, na negligência, no descaso, no desinteresse do titular do direito em exercê-lo. Assim tem decidido, também, o Eg. S.T.F. (Rev. For., $124 / 121-2$ e $105 / 279-82$ ).

Foi esse o comportamento dos advogados consulentes? A resposta só pode ser, seguramente, negativa.

Com efeito.

Desde 1952, ou seja, há 31 anos, se entregaram os consulentes na defesa de seu constituinte, propondo, a primeira das ações por eles ajuizadas, a qual, sempre no bom combate, lograram vitoriar-se, na derradeira instância, o Plenário do Egrégio Supremo.

Depois, foram as tratativas amigáveis como queriam os interessados para a execução do acórdão. Já quase exitosos, ao cabo de três anos, viram, imotivadamente, revogados seus mandatos.
Daí os procedimentos de que se valeram para se verem pagos. A primeira das ações em 1969. O procedimento administrativo, ao habilitarem seu crédito nos autos da sobrepartilha, iniciada em 1974. A seguir, na outra ação proposta contra os herdeiros de Lídio Floriano Melo, a qual findou por acordo. Por último, a que se iniciou em 1981.

E, tudo isso, para receberem seus honorários profissionais pelos serviços prestados. Proporcionaram seu pertinaz labor vultoso patrimônio aos herdeiros de Narciso Melo, no qual não seriam aquinhoados não fossem, repita-se, seus ingentes e longos esforços, como competentes advogados.

Tudo está a evidenciar que o reconhecimento da prescrição não se poderia ter alimentado em boas fontes do Direito.

5. Como ficou bem deduzido nas considerações da seção anterior, se é certo que a revogação dos mandatos originou o direito aos advogados consulentes de receberem a totalidade dos honorários contratados, todavia, seu recebimento estava a depender das condições suspensivas introduzidas na própria avença, somente realizadas posteriormente.

Basta ter presentes as cláusulas antes transcritas, que, sem dificuldade, concluir-se-á que, antes da devolução da estância "Duas Marias", quando seria apurado o seu real valor, e se procedesse à liquidação correspondente à indenização pelo decurso de tempo da ilegal ocupação, satisfeitas não estariam as condições. 
É, pois, da realização de cada uma delas que se há de contar o prazo da prescrição, nos termos do art. 170, I, combinado com os arts. 114 e 118 , todos do Código Civil.

Em abono dessa solução, mostram-se, a meu ver, valiosas as considerações expendidas por Guillouard, em obra célebre, verbis:

“...toutes les fois qu'une créance est conditionnelle, ou à terme certain ou incertain, la prescription commence non du jour où la créance est née, mais du jour où elle est devenue exigible par l'accomplissement de la condition ou l'arrivée du terme. La raison en est que la prescription suppose une négligence du créancier dans l'exercise de son droit, et on ne peut lui reprocher aucune négligence tant que la créance n'est pas exigible."

(In Traité de La Prescription, A. Pedone Éditeur, Paris, 1901, t. $1^{\circ}$, p. 77, n. 77)

E, satisfeitas ambas, há menos de cinco anos da era em que ingressaram em juízo, 08-9-1981, os consulentes, com o procedimento sumaríssimo a que se refere o acórdão comentado, não se teria ultimado o quinquênio estatuído pelo art. 100 da Lei $\mathrm{n}^{\circ}$ 4.215, de 1963.

A tal conclusão se chega, operando com o contrato de honorários ajustado entre o testamenteiro e os advogados consulentes.

6. Posto tenha o douto voto do terceiro juiz reconhecido a responsabilidade do Espólio pelo pagamento dos honorários debatidos, invocando para tanto o disposto nos arts. 1760 e 1137, II, respectivamente, do Cód. Civil e do C.P.C., considerou que não estava ele, Espólio, vinculado às cláusulas do contrato e pelas razões já apontadas anteriormente. Daí não encontrar motivos para considerar as condições suspensivas nele introduzidas.

7. Penso, data venia, que o raciocínio, por demasiado simplista, não concluiu com o devido acerto.

Admito, ad argumentandum, a desvinculação reconhecida. Todavia, sua razão de ser residiria no pertinente ao prejuízo que, porventura, trouxesse aos herdeiros, ou seja, no valor dos honorários, por serem exorbitantes ou excessivos, pois o dever de pagálos o reconheceu o nobre juiz no voto em apreciação. Assim, sobre a percentagem de $35 \%$ contratada. No mais, as cláusulas são até limitativas para os consulentes. E sua invocação fala por si próprio. Ademais, a base sobre a qual assentaria o cálculo é da própria lei, e, tanto o vencimento ordinário como o extraordinário da avença, igualmente, nela assentam, como se vê, da simples leitura, respectivamente, dos arts. 97, in fine, 100 , I, II e V, parte segunda, todos da Lei $\mathrm{n}^{\circ} 4.215$, de 1963.

Assim, também, para o Espólio e os herdeiros, inteiramente válidas eram as condições suspensivas, às quais se impuseram os próprios consulentes e em manifesto favor daqueles.

8. Quando, porém, se venha a aceitar a desvinculação completa e integral do Espólio, aos termos e demais 
cláusulas do contrato de honorários de advogado, como quer o r. voto, ainda assim, não há, data venia, como reconhecer prescrito esteja o direito dos consulentes, obrigandoos a nova demanda, sabe-se lá por quantos anos ainda, para fazerem valer o seu direito, através, então, da ação ordinária de enriquecimento sem causa, direito este nitidamente pessoal, e cuja prescrição é vintenária, nos termos do art. 177 do $C$. Civ. (FONSECA, Arnoldo Medeiros da. In: CARVALHO SANTOS. Repert. Enciclop. do Dir. Bras., v. 20, p. 237-42).

\section{Efetivamente.}

Brotam dos autos e dos documentos deles extraídos e que me foram presentes, de forma quase solar, que duas causas interromperam a prescrição do direito dos autores: as do art. 172, III e V, do C. Civ. Dizem elas:

"Art. 172. A prescrição interrompese:

I - [...]

II - [...]

III - Pela apresentação do título de crédito em juízo de inventário...

IV $-[. .$.

$\mathrm{V}$ - Por qualquer ato inequívoco, ainda que extrajudicial, que importe reconhecimento do direito pelo devedor."

$\mathrm{O}$ primeiro deles, tomado em sua ordem cronológica, é constituído pela já mencionada "CARTA DE COMPROMISSO", subscrita pelos herdeiros, firmada em 15-9-1972, em instrumento particular, subscrito, também, por duas testemunhas, e jamais impugnado.

Dele cumpre destacar duas de suas cláusulas, as de números 2 e 8 . Seu texto integral é o que segue:

"[...]

2) Os signatários se comprometem a concordar que o imóvel em questão, seja dado em arrendamento ou parceria a terceiros, mesmo por prazo superior ao fixado para a indivisibilidade, para que, com a renda sejam atendidos os encargos do imóvel, inclusive os correspondentes às despesas judiciais e os honorários devidos pela propositura da ação de anulação da cessão ou venda de direitos hereditários a Orivaldo Lara Palmeiro e consequente execução da sentença;

[...]

8) Todos os condôminos participarão na proporção de seus quinhões de todas as dívidas, obrigações e despesas contraídas ou feitas no interesse dos condôminos e referentes ao imóvel denominado "Fazenda Duas Marias" excluídas, porém NAIR MELLO e VILMA MELLO GOMES DE OLIVEIRA do que é devido pelos condôminos aos advogados Edgar Wilson Mondadori, Carlos Alberto Mondadori, Cyro de Carvalho Santos, Edilberto Degrazia e Ricardo Talaia O'Donell."

Tenho, por inequívoco, o reconhecimento da dívida dos consulentes, referente a seus 
honorários, pelos herdeiros; e, assim, servindo de causa interruptiva da prescrição, na data de sua lavratura, tal como o requer o citado inciso $\mathrm{V}$ do art. 172, do C. Civ., antes transcrito.

Trata-se de instrumento pelo qual os condôminos da estância "Duas Marias", ainda então indivisa, se propunham arrendá-la. Por isso, comprometiam-se, como o denominaram na CARTA, a repartir as rendas que adviriam, as quais caberiam pro rata a cada um, e, bem assim, as despesas, entre as quais precisavam os honorários em questão, tendo até o cuidado de especificar a ação da qual decorriam e da sua própria execução. Dita cláusula 2 casa-se, perfeitamente, com aquela que consta do contrato de honorários, na ordem oitava e antes também transcrita, onde se declina uma das formas do recebimento dos honorários, ou seja, com os recursos das rendas da estância em questão.

E reiteraram os herdeiros seu dito compromisso, incluindo outros além dos consulentes, mas que trabalharam nas causas; explicando-se a ressalva de duas delas por que se teriam proposto pagar a parte que julgavam devida, a qual resultou em depósito judicial, procedido em 1974.

Nem os comentadores do preceito em menção (art. 172,V), exigem atributos outros para $o$ ato interruptivo.

A propósito, sinala CÂMARALEAL, em sua monografia anteriormente citada, após versar o tema e a doutrina, inclusive no Direito Alemão, baseado em Plank, cuja opinião transcreve (ob. cit. p. 225), verbis:
“[...]

Resumiremos, pois a interpretação do dispositivo legal, dizendo: sempre que o sujeito passivo pratique algum fato ou faça alguma declaração verbal ou escrita, que não teria praticado ou feito, se fosse sua intenção prevalecer-se da prescrição em curso, esse ato ou declaração, importando em reconhecimento direto ou indireto do direito do titular, interrompe a prescrição."

No mesmo sentido são os ensinamentos de CLÓVIS (ob. cit. v. I, p. 444, $\mathrm{n}^{\circ}$ 5); CARVALHO SANTOS (Cód. Civ. Bras. Interp. III, 2. ed., p. 430-1, $\mathbf{n}^{\circ}$ 7); CAIO MÁRIO (Instituições de Dir. Civ. I, 1978, p. 606).

E esta tem sido a orientação da jurisprudência, sempre pacífica, do S.T.F.

Votando, no julgamento do RE $\mathrm{n}^{\circ}$ 7.952, em 20-7-1944, assinalava o saudoso Min. Castro Nunes: “... o ato inequívoco pode ser indireto para o reconhecimento..." (Rev. dos Tribs., 162/363).

Na mesma linha é o que se lê no julgamento do $R E \mathrm{n}^{\circ} 4.416$, em 01-8-44, através da palavra de seu eminente e saudoso Min. Orosimbo Nonato. Admitiu ele que $o$ ato interruptivo pudesse até ser virtual, não se fazendo mister fosse ele expresso. $\mathrm{O}$ que se faz necessário é que, inequivocamente, se relacione com a dívida reconhecida (Rev. For., 103/53-4).

Igualmente, ficou assentado no $\mathrm{RE}$ $\mathrm{n}^{\circ}$ 8.558, em julgamento de 17- 
10-1944, quando aquele eminente Ministro, como relator, admitiu, fundado em autores estrangeiros, que o reconhecimento em observação poderia até mesmo ser verbal, o que autoriza concluir que qualquer meio, desde que inequívoco se faz válido para o fim interruptivo (Rev. For., 105/80-1).

É no sentido exposto o pensar dos doutos: Baudry-Lacantinerie, in Traité Théorique et Pratique de Droit Civil (De La Prescription), Librairie Du Recueil, Paris, 1899, t. XXV, p. 325, n. 529; Henri de Page, in Traité Élémentaire de Droit Civil Belge, Établissements Émile Bruylant, Bruxelles, 1943, t. $7^{\circ}$, v. II, pp. 1.078/1.080, n. 1.194; L. Guillouard, in. Op. cit., pp. $230 / 2, n^{\circ}$ s 247/248.

Dispensável, dessarte, a invocação de julgados ou opiniões de doutores outros para evidenciar que a CARTA DE COMPROMISSO revela, de forma inequívoca, o reconhecimento da dívida, e, consequentemente, por hábil, interrompeu o prazo da prescrição na data em que foi firmada.

9. Cumpre, por fim, verificar da causa final que também teria interrompido o fluxo prescricional. Refiro-me à do já citado art. 172, III, pela apresentação do título de crédito no juízo de inventário.

O inventário, no caso, diz respeito à sobrepartilha, procedida no acervo devolvido: a estância "Duas Marias" e o líquido apurado pela sua ilegal ocupação. Pois foi nesse procedimento administrativo que se verificou a apresentação do título de crédito dos consulentes. Dito título é o mesmo que embasa a presente ação: o contrato de 31-5-1952. Nem os autores dispõem de outro. Em decorrência dele é que o inventariante Lídio, em suas declarações, nos autos da referida sobrepartilha, procedeu à sua descrição, em 16-4-1975. Fê-lo em cumprimento ao disposto no art. 993, IV, f, do C.P.C.; e, mais tarde, no decurso do demorado andamento do feito, se dispôs à separação de bens para seu pagamento.

E foi, não somente diante das declarações em apreço como da apresentação, em 21-12-1976, pelos consulentes de seu título de crédito, que, frente às impugnações dos herdeiros e do legatário, Hospital São Patrício, o juiz despachou, encaminhando a pretensão às vias ordinárias, o que ocorreu em 288-1980 (fl. 322), dos autos da sobrepartilha em questão.

Dessarte, além da interrupção da prescrição anteriormente verificada, com a CARTA de 15-9-1972, outra se operou, posterior, com a citada apresentação do título de crédito, pelos credores, no juízo de inventário, no caso a sobrepartilha.

10. Pouco influi o largo espaço de tempo que medeou entre a citada apresentação do título, em 21-121976, e o despacho do magistrado, ocorrido em 28-8-1980, de resto, inferior a cinco anos. É que, enquanto, vigilantes, aguardavam o pronunciamento dos herdeiros $\mathrm{e}$ demais interessados, e processavase o feito, até que o juiz decidisse a respeito, persistia seu propósito de cobrar, obstando fluxo prescricional. Tal comportamento dos credores, 
posto que, em processo de inventário, equipara-se ao ajuizamento da própria ação de cobrança, como se pode extrair da conjugação do art. $1796, \S \S 1^{\circ}$ e $2^{\circ}$, do C. Civ., e arts. 1018 e seu parágrafo único e 1039 , I, in fine, do C.P.C.

Neste sentido é a lição dos autores, dos quais invoco apenas CARPENTER (Manual Paulo Lacerda III, já cit., p. 287); ALMEIDA OLIVEIRA (A Prescrição, p. 122); OLIVEIRA CASTRO (Cód. Civ. Interp. pelo S.T.F., II, p. 77) e BRENO FISCHER (A Prescrição nos Tribunais, II, 1957, p. 288 e segs., $\S 253$ ), invocando excelente julgado do Trib. de Justiça de S. Paulo, in Revista Forense, 108/316-7, da lavra do saudoso processualista Herotildes Lima, cuja expressiva ementa dispõe:

"Honorários médicos. Prescrição. Interrupção.

A apresentação do crédito de honorários no juízo do inventário produz interrupção da prescrição que só recomeça a correr depois de decidida a remessa do credor às vias ordinárias."

11. A longa e detalhada exposição, por vezes até demasiado insistente, evidencia que, quando os autores, ora consulentes, ajuizaram sua ação de cobrança contra os herdeiros de Narciso Melo - 08-9-1981 - através do procedimento sumaríssimo, prescrito não se achava o seu direito, mesmo que se levasse em consideração a desvinculação completa entre o contrato de honorários e os herdeiros em questão, ora demandados.

$\mathrm{E}$ isto porque:

a) iniciado o prazo em 29-11-1969 com a propositura da primeira das ações, sofreu interrupção com o reconhecimento da dívida pela "CARTA COMPROMISSO" de 15-9-1972;

b) passando o prazo de novo a fluir da última das datas, foi novamente interrompido em 21-12-76, com a apresentação do título de crédito no juízo do inventário (sobrepartilha);

c) e porque dita interrupção é de efeito prolongado (BRENO FISCHER, ob. e vol. cit. p. 288, primeira parte) só findou em 02-8-1980, quando, pondo termo ao pedido de pagamento, despachou o juiz, encaminhando os credores às vias ordinárias; contandose daí, de novo, o prazo;

d) ajuizada a derradeira ação em 08-91981, não decorreram os cinco anos, prazo prescricional estatuído pelo art. 100 da Lei $\mathrm{n}^{\circ} 4.215$, de 1963, seja da última das datas mencionadas, seja da penúltima delas." 25

Os seus pareceres lembram, na forma de deduzir e de concluir, o mesmo estilo dos tempos de juiz: 
o modo límpido e correntio que notabilizaram as suas sentenças e acórdãos.

Em expressiva homenagem que lhe foi prestada pela academia, logo após a sua aposentadoria, o saudoso Desembargador Mário Boa Nova Rosa delineou com fidelidade o perfil do jurista Carlos Thompson Flores, verbis:

"O juiz Carlos Thompson Flores, porque juiz ele foi todo, só e sempre, teve a Justiça, com esses conceitos, como o breviário em que assentou a sua fé no primado do Direito.

Não tomou, porém, esses princípios, como armadura ou como escudo, mas brandiu-os, como lança ou como gládio, durante toda sua longa, brilhante e prestimosa vida de julgador. Mesmo afastado já da esperança sem temor, da mocidade; mas ignorando também o temor sem esperança dos que não têm mais futuro, acreditou sempre no poder da Lei e na majestade da Justiça.

Foi bem o tipo clássico do magistrado de carreira, que fez do hábito de julgar um sincero apostolado e só compreendeu o Direito como uma obrigação superior, pairando acima dos interesses e das paixões.

Nunca foi mero aplicador da lei; nem simples compulsador de ementários de jurisprudência; e, muito menos, um insensível aos dramas humanos que a realidade, surpreendentemente, suscita, alguns com aparência de insolúveis. Pelo contrário, timbrou sua fecunda caminhada com provas incontroversas de penetrar no âmago da lei, subtraindo da norma sua essência de justiça, para conciliar o interesse público com as pretensões privadas das partes, não sacrificando o direito, nem sendo rigoroso ao extremo, nem tolerante em demasia; porque fez dos repositórios de julgados a bússola de suas convicções sobre o contexto social do momento, sem tornar-se subserviente com o fim escuso de aumentar a probabilidade de serem as sentenças mantidas, com um -falso halo de prestígio, mesmo contrariando as verdadeiras ideias de seu subscritor não reveladas; sempre se despiu do aparato de autoridade intransigente que, de fato, nunca se impõe, embora possa ser temida, para revestir-se de autoridade branda, mas firme.

Proferiu decisões que ficaram assinaladas com a sua marca, pois, como refere Lourenzo Carnelli, nenhum julgador se despoja inteiramente de seus hábitos, inclinações e preferências, que gravitam em torno de suas decisões, sem que ele o queira ou saiba. Pode, se exercitar a centelha divina que Deus põe em sua mente, realizar a função criadora reclamada por Alberto V. Fernandez, advogado e professor argentino, do juiz, para quem as normas jurídicas gerais são esboços, incompletos objetos, obscuros e, às vezes, toscos, que o intérprete estuda, analisa e penetra com toda a ciência ao seu alcance.

$\mathrm{O}$ pragmatismo de sua longa formação de juiz pareceu, quiçá, formalista... Mas esse formalismo traduzia a pureza de seus métodos de 
jurista clínico, que tanto valorizava a perfeição do diagnóstico quanto enfatizava a adequação, a cada mal específico, da terapêutica própria. No mais, mesmo em questões de índole formal, foi benevolente $\mathrm{e}$ tolerante, trazendo aos textos rígidos e frios o abrandamento que sua inclinação temperamental impunha. Do juiz profissional, justamente envaidecido de sua carreira e da missão augusta que desveladamente cumpriu; do juiz liberal em quem a ânsia de fazer justiça às partes tornava reparador intransigente das violações à liberdade, não só dos probos e dos justos, mas de todos, sem discriminações nem fronteiras outras que as da lei; do juiz exato na transigência, generoso na severidade, humano na disciplina - de um juiz assim dotado pode se dizer que nasceu para a mais alta Corte de Justiça, indo nela encontrar a mesma atmosfera que seu modo de ser desde sempre respirara.

[...]

No grande volume que é a vida de S. Ex ${ }^{a}$. a sua atuação como juiz ficará assinalada entre duas folhas: a longínqua e modesta pretoria de Herval do Sul e a recente e magnífica presidência da Corte Suprema; mas, ao contrário da flor esmaecida que, para lembrança de alguém, se conserva entre as páginas de um livro, seu exemplo não perderá o viço na memória de seus contemporâneos e servirá de modelo para os porvindouros."26

A morte alcançou-o em 16.04.2001, aos 90 anos de idade.

Em 15.08.2001, o Instituto dos Advogados do Rio Grande do Sul conferiu-lhe a Comenda Honorífica "Magistrado Exemplar" post mortem, num público reconhecimento aos seus elevados méritos como juiz e jurista.

No decorrer de quase meio século, repetindo Bento de Faria, o Ministro Carlos Thompson Flores distribuiu justiça sem os excessos da mediocridade exibicionista, praticou o bem sem alardes; elevou o conceito de nossa Pátria, honrou a sua toga, impôs-se ao respeito e admiração dos seus pares e jurisdicionados, avassalou os corações de quantos serviram ao seu lado e sobretudo os dos que continuarão a fruir o proveito dos seus ensinamentos.

Nos merecidos aplausos que rodeiam a longa trajetória do Ministro Carlos Thompson Flores, resplandece a qualidade mestra de todo homem marcante: a fidelidade a si mesmo, à sua vocação e aos seus ideais de justiça. Foi nesse nobre sentimento que acumulou forças para contrariar os poderosos, para amparar os fracos, para desprezar a momentânea e falsa

26 In: Revista Estudos Jurídicos, v. XI, nº 32, ano 1981, p. 102/3. 
opinião das multidões e para servir o interesse superior da Justiça.

Afirmou um magistrado francês que "c'est mal définir la grandeur du magistrat, que de ne la faire connaître que par son pouvoir. Son autorité peut commencer ce tableau, mais sa vertu seule peut l'achever. C'est elle qui nous fait voir en lui l'esprit de la loi et l'áme de la justice; ou plutôt il est, si l'on peut parler ainsi, le supplément de l'une et la perfection de l'autre. Il joint à la loi, souvent trop générale, le discernement des cas particuliers; il ajoute à la justice cette équité supérieure sans laquelle la dureté de la lettre n'a souvent qu'une rigueur qui tue, et l'excès de la justice devient quelquefois l'excès de l'iniquité". ${ }^{27}$ Nenhuma sentença literária seria mais apropriada de esclarecer a magistratura de Carlos Thompson Flores como essa de D'Aguesseau, ao revelar o segredo da projeção de sua jurisprudência que se prolongará pelo tempo afora, pois soube marcar acima dos interesses dos homens e das contingências do momento para representar o mais puro ideal da Justiça, como aquele expresso por Bossuet em presença de Luiz XIV, verbis:

\begin{abstract}
"Deve ela - a justiça - ser presa a regras. Inegável em sua conduta, conhecendo o verdadeiro e o falso nos fatos que expõe. Deve ser ainda cega em sua aplicação. Sobretudo, deve ser branda algumas vezes, dando lugar à indulgência. Finalmente, a Justiça é insuportável nos seus rigores. A constância a fortalece nas regras; a prudência a esclarece nos fatos; a bondade lhe faz compreender as misérias e as fraquezas. Assim, a primeira a sustenta; a segunda, a aplica; a terceira, a tempera. Todas as três virtudes a tornam perfeita e a completam por seu concurso". ${ }^{28}$
\end{abstract}

Virtus praestat ceteris rebus.

27 In: Oeuvres Choisies Du Chancelier D'Aguesseau, Librairie de Firmin Didot Frères, Paris, 1863, p. 108.

28 In: Oeuvres de Bossuet, Firmin Didot Frères, Paris, 1862, t. I, p. 421. 
$\because$ 